\title{
VALORAÇÃO MONETÁRIA DE BENEFÍCIOS AMBIENTAIS: O CASO DO TURISMO NO LITORAL CEARENSE
}

FRANCISCO CASIMIRO FILHO

Engenheiro Agrônomo

Orientador: Prof. Dr. RICARDO SHIROTA

Dissertação apresentada à Escola Superior de Agricultura "Luiz de Queiroz", Universidade de São Paulo, para obtenção do título de Mestre em Ciências, Área de Concentração: Economia Aplicada

P I R A C I C A B A

Estado de São Paulo - Brasil

Janeiro - 1998 
Dados Internacionais de Catalogação na Publicação (CIP)

DIVISÃO DE BIBLIOTECA E DOCUMENTAÇÃO - Campus "Luiz de Queiroz"/USP

\section{Casimiro Filho, Francisco}

Valoração monetária de benefícios ambientais: o caso do turismo no litoral cearense / Francisco Casimiro Filho. . . Piracicaba, 1998.

$81 \mathrm{p}$.

Dissertação (mestrado) - E Escola Superior de Agricultura Luiz de Queiroz, 1998. Bibliografia.

1. Fortaleza, CE 2. Praia (conservação) 3. Recursos naturais 4. Turismo (aspecto econômico) I. Título 


\section{VALORAÇÃO MONETÁRIA DE BENEFÍCIOS AMBIENTAIS: O CASO DO TURISMO NO LITORAL CEARENSE}

Aprovada em: 06/03/1998

Comissão julgadora:

Prof. Dr. RICARDO SHIROTA

ESALQ/USP

Profa. Dra. ZILDA PAES DE BARROS MATTOS ESALQ/USP

Prof. Dr. ROBERTO GUENA DE OLIVEIRA

Prof. Dr. RICARDO SHIROTA Orientador 
NO CEARÁ É ASSIM

"Eu só queria

Que você fosse um dia

Ver as praias bonitas

Do meu Ceará

Tenho a certeza Que você gostaria Dos mares bravios

Das praias de lá

Onde o coqueiro Tem palma bem verde Balançando ao vento Pertinho do céu E lá nasceu a virgem do poema A linda Iracema dos lábios de mel

Oh! Quanta saudade

Que eu tenho de lá Oh! Quanta saudade

A jangadinha vai no mar deslizando

O pescador o peixe vai pescando

$O$ verde mar...

Que não tem fim...

No Ceará é assim".

Carlos Barroso 
Aos meus pais, Chico Casimiro e Socorro que não pouparam esforços para minha formação.

Às minhas irmãs, Sandra, Juliana e Sâmea, pelo incentivo constante. 


\section{AGRADECIMENTOS}

À Secretaria do Turismo do Estado do Ceará - SETUR, especialmente a Hildemar Silva Brasil, Lúcia Maria de Sousa Nabuco e Maria de Lurdes Rocha, que forneceram os dados primários, tornando possivel a realizaçāo deste trabalho.

Aos professores e funcionários do Departamento de Economia e Sociologia Rural - DESR/ESALQ/USP, pelos conhecimentos transmitidos e pelo apoio dispensado.

Ao professor Ricardo Shirota, pela orientação, não só durante a realização desta pesquisa, mas durante todo o curso de mestrado.

Aos professores Carlos José Caetano Bacha e Zilda Paes de Barros Mattos pelas valiosas sugestões durante a realização do exame de qualificação.

Aos membros da banca examinadora professores Dr. Roberto Guena de Oliveira, Dra. Zilda Paes de Barros Mattos e Dr.Ricardo Shirota pelas valiosas criticas e sugestões para melhoria deste trabalho.

À bibliotecária do DESR Angélica pelas correções das referências bibliográficas.

À Kátia Maria da Silva e Euclides Gomes Parente Filho pela coleta e sistematização das informações referentes ao preço de passagens de ônibus para Fortaleza.

À professora do Departamento de Economia Agrícola, da Universidade Federal do Ceará, Maria Irles de O. Mayorga, exemplo de coragem e determinação, pela a oportunidade de conhecer essa área de trabalho, bem como pelos seus ensinamentos tanto no campo profissional como no pessoal. 
Ao Serviço Social do Campus de Piracicaba, pela concessão da moradia na Vila Estudantil, onde tive a oportunidade de conhecer pessoas com as quais aprendi bastante.

Aos irmãos e irmās de moradia que fizeram com que essa caminhada fosse menos árdua.

À funcionária da biblioteca do DESR e amiga Luciane, que sempre esteve pronta para ajudar independente da situação.

À duas grandes amigas/irmãs, Piedade e Cláudia pelo estimulo, companheirismo e apoio constante durante essa caminhada, por isso sabem mais do que ninguém a história deste trabalho.

Aos colegas de curso, especialmente a Silvia Miranda, Marina Silva, Carliton Vieira, Marcos Hasegawa e Alexandre Florindo, pela agradável convivência, apoio e amizade durante a realização do curso.

À todos os amigos que fiz no decorrer da minha estadia em Piracicaba, que graças a Deus foram muitos, assim não os listarei para não cometer omissões.

A Deus, pela minha existência e pela perseverança em todos os momentos da minha vida.

Enfim, à todos que direta ou indiretamente contribuiram para que mais essa parte da caminha fosse vencida. 


\section{SUMÁRIO}

Página

LISTA DE FIGURAS .................................................. vii

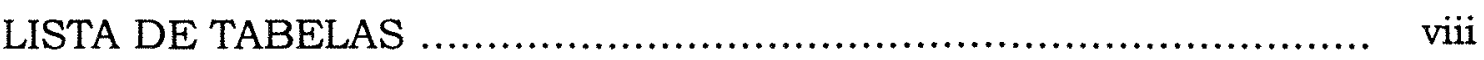

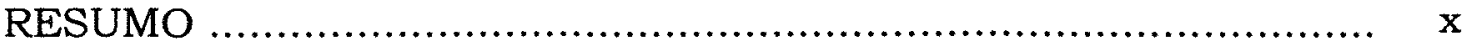

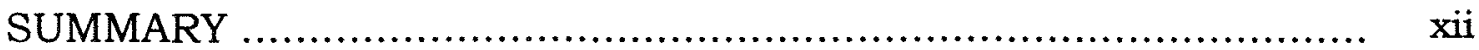

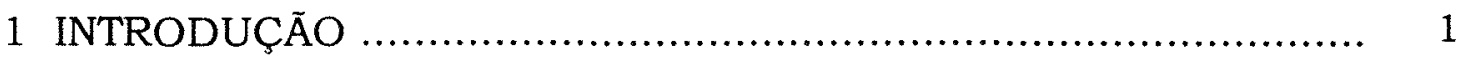

1.1 A importância do turismo ....................................... 1

1.2 Definição do problema e justificativa do estudo ................... 5

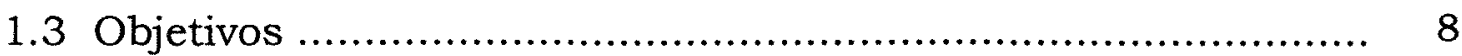

1.4 Estrutura do trabalho .............................................. 9

2 REVISÃO DE LITERATURA ........................................... 10

3 REFERENCIAL TEÓRICO E METODOLÓGICO .......................... 17

3.1 Referencial teórico .................................................. 17

3.1.1 Fontes de ineficiência associadas ao recurso ambiental ............. 17

3.1.1.1 Não-exclusividade ................................................ 18

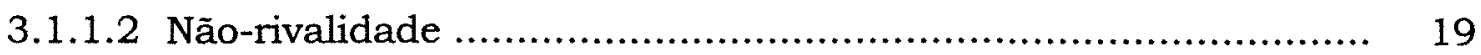

3.1.1.3 Bens congestionáveis ............................................. 20

3.1.2 Definição do valor de recurso ambiental ............................. 21

3.2 Métodos de valoração de áreas de recreação ...................... 22

3.2.1 Método da valoração contingencial .................................... 23

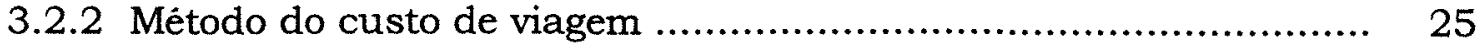

3.2.2.1 Problemas enfrentados em decorrência do uso do MCV ............ 28 
3.2.2.2 Especificação da função e das variáveis ................................ 29

3.3 Aplicação do método do custo de viagem ......................... 34

3.3.1 Custo de viagem ................................................................ 36

3.3.2 Custo de transporte ......................................................... 39

3.3.3 Variáveis sócio-econômicas ................................................. 40

3.3.4 Variáveis comportamentais e dummy .................................... 41

3.3.5 O modelo empírico para a função de demanda por turismo ......... 42

3.3.6 A estimativa do valor de uso das praias ................................... 44

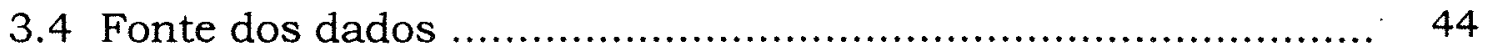

4 RESULTADOS E DISCUSSÃO _........................................... 46

4.1 Avaliação da demanda turística ....................................... 46

4.1.1 Local de origem dos visitantes ........................................... 47

4.1.2 Freqüência de visitação ao Ceará ............................................ 48

4.1.3 Idade e sexo dos visitantes ................................................ 50

4.1.4 Renda, tipo de transporte e meio de hospedagem utilizados pelos

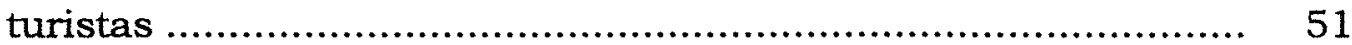

4.1.5 Nível de escolaridade, estado civil, composição do grupo e motivo da viagem dos turistas ....................................................... 53

4.2 Estimativa da função de demanda por turismo no litoral cearense ............................................................. 56

4.3 Estimativa do valor recreacional das praias cearenses .......... 66

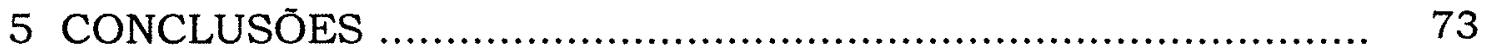

REFERÊNCIAS BIBLIOGRÁFICAS .................................. 76 


\section{LISTA DE FIGURAS}

Página

1 Desempenho do turismo internacional no Brasil, medido pelo número de turistas e pela receita gerada, 1983-1993 ..............

2 Avaliação da demanda turistica segundo a idade e o sexo dos visitantes e freqüència de visitação .....................................

3 Avaliação da demanda turistica segundo o tipo de transporte e o meio de hospedagem utilizados 


\section{LISTA DE TABELAS}

Página

1 Número de hóspedes registrados nos hotéis classificados de Fortaleza e receita do turismo no Estado do Ceará

2 Principais Estados brasileiros emissores de turistas para o Estado do Ceará e percentagem de turistas nacionais e estrangeiros

3 Classe de renda mensal familiar dos turistas que visitaram o Estado do Ceará, nov./95 e classes de renda das pessoas de 10 anos ou mais de idade, Brasil, 1995

4 Nivel de escolaridade dos turistas que visitaram o Ceará.

5 Estado civil por composição do grupo de viagem dos turistas que visitaram o Ceará

6 Principal motivo da viagem por composição do grupo de viagem dos turistas que visitaram o Ceará

7 Estimativa dos parâmetros da função de demanda por turismo, Estado do Ceará, nov./95, forma linear

8 Estimativa dos parâmetros da função de demanda por turismo, Estado do Ceará, nov./95, forma semi-log na variāvel dependente 
9 Estimativa dos parâmetros da função de demanda por turismo, Estado do Ceará, nov./95, forma log-log ...............................

10 Estimativa dos parâmetros da função de demanda por turismo, Estado do Ceará, nov./95, forma semi-log nas variáveis independentes .......................................................

11 Estimativas dos variance inflation factrs para as formas funcionais linear, semi-log na variável dependente, log-log e semi-log nas variâveis independentes da função de demanda por turismo, Estado do Cearä, nov./95

12 Estimativa do valor recreacional das praias do litoral cearense e custos de viagem máximo e minimo em cada uma das categorias de turistas

13 Estimativa do valor recreacional das praias do litoral cearense, número de turistas e valor de uso ponderado em cada uma das categorias de turistas 


\title{
VALORAÇÃO MONETÁRIA DE BENEFICIOS AMBIENTAIS: O CASO DO TURISMO NO LITORAL CEARENSE
}

\author{
Autor: FRANCISCO CASIMIRO FILHO \\ Orientador: Prof. RICARDO SHIROTA
}

\section{RESUMO}

O objetivo do presente estudo foi o de estimar os beneficios do turismo no litoral de Fortaleza e região, no Estado do Ceará. Por não possuirem preços de mercado esses beneficios não podem ser mensurados através da teoria econômica tradicional. Nesses casos, eles podem ser mensurados indiretamente através da valoração monetária das amenidades que são exploradas pela atividade. Para isso utilizou-se o método do custo de viagem.

Esse método usa os custos incorridos pelos individuos, quando viajam para um determinado local de recreação, como proxy do preço do bem ou serviço explorado pela referida atividade. A partir de informaçōes como custo de viagem, taxa de visitação e variáveis sócio-econômicas, estima-se a curva de demanda e o excedente do consumidor. Este último é utilizado como uma estimativa do valor de uso do local explorado.

Os dados primários para este trabalho foram obtidos da Pesquisa de Demanda Turística, realizada pela Secretaria do Turismo do Estado do Ceará. As informações referem-se aos turistas que visitaram as praias do litoral cearense no mês de novembro de 1995. 
Analisando o perfil desses turistas, constatou-se que ainda é baixa a percentagem de estrangeiros $(7 \%)$. Dentre os turistas domésticos a grande maioria é proveniente da região sudeste do Brasil.

Os resultados mostraram que $41,2 \%$ dos turistas estavam visitando o Estado pela primeira vez, demonstrando a importância dos "novos clientes". Dos turistas amostrados $53 \%$ possuiam idade entre 26 e 40 anos, sendo portanto um público relativamente jovem e que tem como principal motivo da viagem a procura de lazer e recreação. Os turistas amostrados revelaram, ainda, ter um alto poder aquisitivo, se comparado com a maioria da população brasileira, bem como um alto grau de escolaridade.

De posse dessas e de outras informações sobre as caracteristicas sócio-econômicas dos turistas e dos seus custos de viagem, foi possivel estimar uma função de demanda por praia. Os resultados permitiram concluir que se tratava de uma função de demanda inelástica com relaçāo ao preço. Integrando-se essa função, do ponto cujo custo de viagem foi minimo, até o ponto onde o custo de viagem foi máximo, obteve-se um valor de uso estimado para as praias do litoral cearense de $\mathrm{R} \$ 144,12$ por turista por dia.

Assim, pôde-se concluir que as praias do litoral cearense são importante fonte geradora de beneficios para a sociedade brasileira e que, por isso devem ser conservadas. Dessa forma, por se tratar de um recurso ambiental e que possui características de bens públicos, deve ser conservado pelo poder público, seja ele federal, estadual, ou municipal. 


\title{
MONETARY VALUATION OF ENVIRONMENTAL BENEFITS:THE CASE OF TOURISM IN COASTAL CEARÁ
}

\author{
Author: FRANCISCO CASIMIRO FILHO \\ Adviser: Prof. RICARDO SHIROTA
}

\section{SUMMARY}

The aim of this study was to evaluate the benefits of tourism in coastal Fortaleza and surroundings, in the state of Ceará. Such benefits are not liable to be measured through traditional economic theory since they lack market prices. In these cases, however, they can be indirectly measured through the monetary valuation of the amenities involved by the activity. The travel cost method was used.

This method uses the cost incurred by individuals while traveling to a particular recreational site as the asset price proxy or service exploited by the activity. The travel cost, visitation fee, and socioeconomic variables were used to estimate the demand curve and the consumer's surplus. The latter was used as an estimate of the use value of the site.

The data used in this work came from the Tour Demand Research, carried out by the Secretaria do Turismo do Estado do Ceará. The informs refer to the tourists visiting the beaches in the month of November, of 1995. 
The profile analysis of these tourists showed that the percentage of foreign visitors is still low (7\%). Among the domestic tourists, the greater part come from the Southeastern region of Brazil.

The results show that $41.2 \%$ of tourists were visiting the state for the first time, showing that the activity has to gain new clients. Tourists between 26 and 40 years of age represented $53 \%$ of the sample which is a relatively young public in search for leisure and recreation. The sample also showed that the tourists have a relatively high income when compared to the majority of the Brazilian population. Also, they have a high educational level.

With these, and other information of the socioeconomic characteristics and traveling costs, a function of the tourists demand per beach was estimated. The results led to the conclusion that the demand has a relative low elasticity in regards to price.

By integrating this function, from the minimum of the travel cost up to maximum cost, an use value of $\mathrm{R} \$ 144.12$ per tourist per day was estimated for the beaches in coastal Ceará. Only domestic tourists were considered.

Thus, one concludes that the beaches in coastal Ceara are an important source of environmental benefits for the Brazilian society and therefore must be preserved. Accordingly, as an environment resource with public assets characteristics they must be preserved either by the federal, state and municipal public authorities. 


\section{INTRODUÇÃo}

\subsection{A importância do turismo}

Nos últimos anos, uma das preocupações da maioria dos paises tem sido a implantação de atividades que contribuam para o desenvolvimento econômico, sem comprometer o uso eficiente dos recursos naturais, ao contrário, contribuam para a sua conservação. Neste contexto, a atividade turistica desponta como uma alternativa que pode enquadrar-se em um programa de desenvolvimento, funcionando como um instrumento estimulador, principalmente em áreas possuidoras de paisagens exóticas (Melo, 1988). Uma das razões para isso é o baixo nivel relativo de investimentos requeridos para sua implantação, em comparação a qualquer outra indústria, o que a torna recomendável para regiões com recursos financeiros escassos (Lopes, 1990).

Segundo D'Amore (1990), o turismo è a maior indústria do mundo, com expectativa de crescimento futuro. Além disso, se muito bem planejado, não polui o meio ambiente nem degrada os recursos naturais e pode contribuir positivamente para o desenvolvimento econômico. Nesse sentido, o turismo vem desempenhando importante papel na geração de divisas na recente história de alguns paises. Na Austrália, a indústria do turismo é a maior atividade geradora de divisas e contribui com aproximadamente 5,6\% do Produto Interno Bruto - PIB (Bontempo, 1994). A Costa Rica possui $20 \%$ do seu território protegido por lei na forma de parques 
e reservas nacionais, que são explorados pela atividade turística. Este setor é a segunda maior fonte de divisas para o País. No ano de 1993, rendeu cerca de $7,7 \%$ do PIB (Burnie, 1994).

No Brasil, o turismo internacional apresentou taxas crescentes de desempenho até o terceiro quartil da década de oitenta, quando passou a ter desempenho decrescente até o início dos anos noventa. Em seguida a essa fase, o turismo vem apresentando reações positivas no que diz respeito ao número de chegadas de turistas (Figura 1). No ano de 1993, o turismo gerou algo em torno de US\$ 1,5 bilhão de dólares, ocupando assim o sétimo lugar como atividade geradora de divisas do país (Bontempo, 1994).

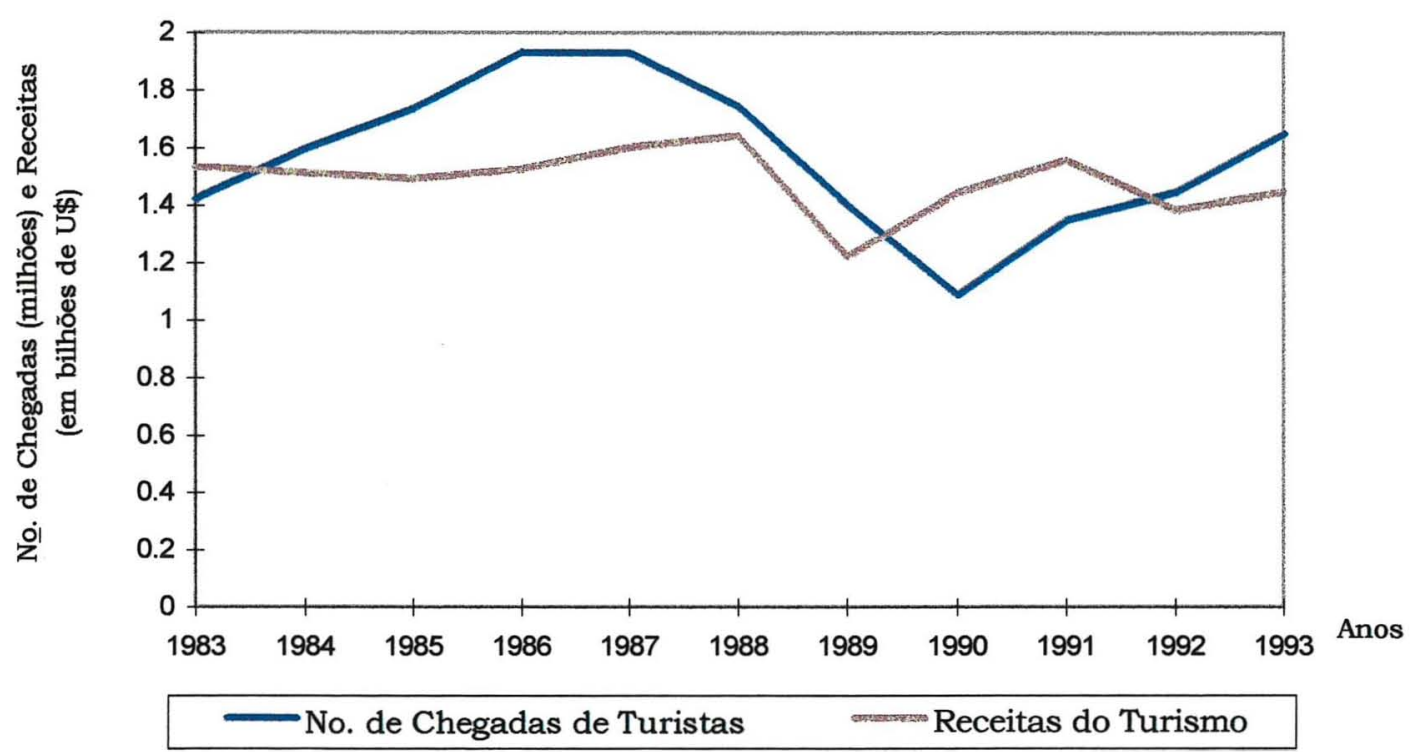

Fonte: Caracristi (1994)

Figura 1 - Desempenho do turismo internacional no Brasil, medido pelo número de turistas e pela receita gerada, 1983 - 1993.

Com relação ao turismo doméstico ou turismo interno no Brasil, não há dados disponiveis. Não existem controles administrativos dos deslocamentos das pessoas que não ultrapassam as fronteiras internacionais, 
o que demonstra a falta de um planejamento para o setor por parte dos órgãos competentes.

No Estado do Ceará, a partir da década de 80 , vem se intensificando o desenvolvimento da atividade turistica. Segundo estimativas do Instituto de Planejamento do Ceará - IPLANCE, a receita total gerada pelo turismo no Estado varia em torno de $2 \%$ do PIB estadual (ver Tabela 1).

Tabela 1. Número de hóspedes registrados nos hotéis classificados de Fortaleza e receita do turismo no Estado do Ceará, 1988 - 1994

\begin{tabular}{cccc}
\hline Ano & No de Hóspedes & $\begin{array}{c}\text { Receita do } \\
\text { Turismo (em US\$) }\end{array}$ & $\begin{array}{c}\text { Estimativa da Participação } \\
\text { da Receita do Turismo no } \\
\text { PIB do Ceará (\%) }\end{array}$ \\
\hline 1988 & 200.001 & - & - \\
1989 & 231.174 & - & - \\
1990 & 204.710 & - & - \\
1991 & 227.278 & 175.366 .717 & 2,12 \\
1992 & 193.227 & 172.240 .930 & 1,81 \\
1993 & 175.515 & 165.276 .249 & 1,93 \\
1994 & 213.111 & 175.493 .076 & - \\
1995 & 220.419 & 511.644 .240 & -00 \\
\hline
\end{tabular}

Fonte: Anuário Estatístico do Ceará - 1992, 1993, 1994 e 1995/96.

1 Os dados relativos à receita gerada pelo turismo são dificeis de serem obtidos; os apresentados são estimativas feitas pelo IPLANCE.

Além de fonte geradora de renda, a indústria do turismo é uma das atividades que mais cria empregos no mundo. Estima-se que 204 milhões de pessoas dependem direta ou indiretamente do turismo, representando um em cada nove trabalhadores empregados (Organização Mundial de Turismo OMT). Em relação ao Brasil, estima-se que essa atividade gera em torno de 1,5 
milhão de empregos diretos e indiretos (Bontempo, 1994). Segundo a Fundação Instituto de Pesquisas Econômicas' ${ }^{1}$, citado por Rabahy (1990, p. 62), cada emprego gerado no setor turístico resulta em um incremento de aproximadamente 5,5 unidades no emprego total, no Brasil. A atividade turistica pode contribuir também para uma melhoria na distribuição de renda entre as diferentes regiōes. A infra-estrutura montada nas regiōes pobres permite que elas recebam os turistas das regiōes mais desenvolvidas, fazendo com que ocorra uma migração de renda para aquelas áreas.

O Nordeste brasileiro, devido às suas caracteristicas fisicas e naturais e à exuberância do seu litoral, possui um grande potencial para a indústria do turismo. A regiāo vem despertando interesse por parte dos turistas nacionais e estrangeiros, pelas suas belezas naturais e paisagens exóticas. Assim, no final do ano de 1994, foi assinado o Programa de Açāo para o Desenvolvimento do Turismo no Nordeste - PRODETUR, com o objetivo de financiar a montagem da infra-estrutura e desenvolver essa indústria na região, através do planejamento integrado. Esse programa será financiado através de uma parceria entre o Banco Interamericano de Desenvolvimento (BID) e os governo estaduais.

O Estado do Ceará possui uma extensa área de litoral, com 573 $\mathrm{km}$ de praias com águas de temperaturas agradáveis (em torno de $28^{\circ} \mathrm{C}$ ), emolduradas por dunas de areias brancas ou coloridas e, em algumas áreas, exuberantes coqueirais. Este Estado é um dos que vem aproveitando melhor esse potencial turistico, explorando-o como uma das bases da economia. Para montagem da infra-estrutura necessária ao acolhimento dos turistas, o Estado receberá investimentos da ordem de US\$159,19 milhões, num periodo de cinco anos. A liberação da primeira parcela ocorreu em janeiro de 1996 (no valor de R\$ 42 milhōes). O montante destinado ao Estado do Ceará

1 FUNDAÇÃO INSTITUTO DE PESQUISAS ECONÔMICAS. Multiplicadores de renda e emprego no Brasil. Relatório Final, pesquisa para Embratur. São Paulo, dez. 1994. 
corresponde a aproximadamente $19,9 \%$ do volume total de recursos que será investido na atividade turística na região Nordeste através do PRODETUR.

Esse programa, no Estado do Ceará, dará uma maior atenção à montagem da infra-estrutura, tais como: construção e reforma de equipamentos turisticos, construção e manutenção de estradas, esgotamento sanitário e abastecimento de água. Por outro lado, é preocupante o fato de que a defesa e a preservação ambiental são colocados como as últimas prioridades do programa, visto que receberão menor parcela do volume de recursos financeiros 2 .

De fato, a preocupação maior não deveria ser somente com a infra-estrutura, mas também com a conservação das amenidades ambientais. Se degradadas, os turistas não irão mais procurá-las, comprometendo assim a atividade. Ou seja, uma expansão desordenada da atividade turistica poderá provocar uma degradação do meio ambiente e com isso comprometer sua exploração a longo prazo, já que sua recuperação torna-se bastante dificil e praticamente inviảvel economicamente.

\subsection{Definição do problema e justificativa do estudo}

O meio ambiente oferece à sociedade diversos tipos de beneficios. Alguns podem ser valorados com relativa facilidade por possuirem preços de mercado. Este è o caso da produção de alimentos, madeira, minerais, etc. Outros, como recreação/turismo, biodiversidade, processos ecológicos, educação, pesquisa, etc., por não possuirem preços de mercado, são dificeis de serem mensurados monetariamente utilizando a teoria neoclássica "tradicional". No entanto, eles podem ser valorados por outras vias. No caso do

2 Segundo as declarações dadas pela Secretária Estadual de Turismo no Jornal O Povo/Economia (4/01/96). 
turismo, ele pode ser mensurado indiretamente atravês da valoração econômica das amenidades ambientais que são exploradas pela atividade turistica (Hufschmidt et al., 1983). Para isso, faz-se necessário o conhecimento da função de demanda por turismo, a fim de que se torne possivel estimar os beneficios gerados para os turistas.

O valor econômico de uma determinada amenidade ambiental para a sociedade pode resultar tanto do uso direto como do uso indireto (ou uso passivol da mesma. O valor que resulta do uso direto da amenidade é mensurado pelo valor de uso. Jâ o valor que resulta do uso passivo é medido através do valor de opção e do valor de existência ${ }^{3}$ (Pearce \& Turner, 1990).

$\mathrm{Na}$ ausência de mercado, é difícil estabelecer um valor monetário para esses bens. Quando não é possivel obter indicadores de valor monetário, que normalmente são usados no mercado, a solução ê estimar uma função de demanda para os bens através de evidências indiretas. Isso é medido, por exemplo, pelo valor que os usuários de determinadas amenidades estariam dispostos a pagar se as amenidades fossem vendidas no sentido usual, ou seja, cria-se um mercado hipotético a fim de que se possa obter valores para esses bens (Pearse, 1968).

A dificuldade em estabelecer valores para o meio ambiente está associada às caracteristicas dos bens e serviços que o compõem. Muitas dessas caracteristicas geram falhas no funcionamento eficiente dos mercados ${ }^{4}$. Assim, em alguns casos não é possivel estabelecer um preço de mercado para essas amenidades. $\mathrm{E}$, nos casos em que é possivel estabelecer o preço de mercado, este geralmente é menor que o preço eficiente. Isso faz com que haja

3 Esses conceitos serão melhor explicados na seção 1 do capitulo 3 do presente trabalho.

${ }^{4}$ As caracteristicas que geram falhas no funcionamento dos mercados e que estão associadas com este estudo, são: nāo-exclusividade, não rivalidade e congestionamento (bens congestionáveis). Para uma melhor explicação dessas caracteristicas ver o capitulo 3 do presente trabalho. 
uma super exploração das amenidades e, conseqüentemente, sua degradação. O aumento na quantidade demandada de um bem para finalidade de recreação, que possui caracteristicas de bens públicos, pode causar congestionamento no mesmo, provocando assim uma diminuição na qualidade da atividade, bem como na qualidade fisica do ambiente (Pearce \& Turner, 1990; Nickerson, 1990; McConnell, 1977).

Porêm, um planejamento adequado da atividade turistica pode minimizar esses problemas. Dentre outros, esse é um dos principais objetivos do planejamento da atividade turistica (Ruschmann, 1994). No entanto, para essas ações de planejamento da atividade, é de fundamental importância o conhecimento da demanda turistica. Dela dependem o adequado dimensionamento atual, e as projeçōes futuras que determinarāo os ajustes necessários ao bom desempenho da referida atividade nos núcleos receptores (Ruschmann, 1994; Lage \& Milone, 1991).

Dessa forma, as pesquisas de demanda turística devem ser continuas e devem considerar tanto as caracteristicas dos turistas reais como as dos turistas potenciais 5 . A partir da demanda real, é possivel conhecer o perfil dos turistas e seus niveis de satisfação com os serviços turisticos, o que permite uma melhor adequação da oferta desses serviços. Além disso, a partir dos dados da demanda real é que se projetam as tendências de demanda potencial (Ruschmann, 1994). Assim, è de fundamental importância o conhecimento da função de demanda por turismo.

Tal conhecimento, além de contribuir para o planejamento da atividade, serve também para obter estimativas dos beneficios derivados da exploração dessas amenidades. Esses valores podem ser incluídos nas análises de beneficio-custo das diferentes alternativas de uso das amenidades

\footnotetext{
5 A demanda turística real é aquela constituida por turistas que se encontram na localidade receptora. Já a demanda potencial é constituída de pessoas que possuem todas as condições de viajar, mas não o fazem por desconhecerem o local e seus atrativos (Ruschmann, 1994).
} 
em questão (Hufschmidt et al., 1983; Tisdell, 1991). Assim sendo, torna-se importante fazer uma estimativa do valor de uso das praias que estão sendo utilizadas como atrativos turísticos, pois dessa forma estar-se-á contribuindo com dados para trabalhos futuros de análise dos custos e beneficios do turismo. Além disso, será possivel fornecer subsidios aos órgãos responsáveis pela elaboração e execução de politicas de conservação das referidas amenidades ambientais. $O$ valor estimado poderá servir como parâmetro para a determinação do valor de multas (ou outro tipo de punição/compensação) por danos ambientais causados às praias, caso estes venham a acontecer.

\subsection{Objetivos}

O presente estudo tem por objetivo geral estimar os beneficios do turismo no litoral de Fortaleza e região, no Estado do Ceará, beneficios esses que não podem ser mensurados através da teoria econômica tradicional. Especificamente, pretende-se:

a) estimar a função de demanda por turismo, que permitirá conhecer o perfil dos turistas; e,

b) estimar o valor recreacional (valor de uso) das praias do litoral cearense, que permitirá fazer uma estimativa do valor econômico das mesmas.

Embora sabendo-se que os beneficios totais, ou valor total de uma determinada amenidade ambiental, sejam resultado da soma do valor de uso, valor de opção e do valor existência, neste estudo os dois últimos valores não serão estimados. Isso porque, para que fossem estimados, a amostra deveria incluir não só os turistas que visitam as praias, mas, também, as pessoas que embora não as visitem, têm a conservação das praias como parte de sua função utilidade e, desta forma, estariam dispostas a pagar pela sua conservação. 


\subsection{Estrutura do trabalho}

Além deste capitulo introdutório, este trabalho conta ainda com mais quatro capitulos: revisão de literatura, referencial teórico e metodológico, resultados e discussão, e conclusões e sugestões.

No capitulo 2, que trata da revisão de literatura, são apresentados alguns trabalhos empiricos que tratam do problema aqui abordado. São estudos que analisam a disposição a pagar dos usuários de diferentes amenidades ambientais, bem como a estimativa do valor de uso dessas amenidades.

O referencial teórico e metodológico é tratado no capitulo 3 . A primeira seção apresenta algumas considerações teóricas acerca do problema, o que irá facilitar o seu entendimento do ponto de vista teórico. A seçāo seguinte faz uma breve apresentaçāo dos principais métodos utilizados na valoração de amenidades ambientais. Em seguida, é feita uma descrição do método que é aplicado nesse estudo. E, por último, faz-se uma breve descrição da fonte dos dados que é utilizada no presente trabalho.

Os resultados e a discussão são apresentados no capitulo 4 , que foi subdividido em duas partes. Na primeira parte faz-se uma breve avaliação da demanda turistica. $\mathrm{Na}$ segunda parte são apresentados os resultados referentes às estimativas da função de demanda por turismo no litoral cearense e do valor econômico das praias para os turistas.

Por último, no capitulo 5, são apresentadas as principais conclusões do presente trabalho, bem como sugestões para realização de trabalhos futuros. 


\section{REVISÃO DE LITERATURA}

Vários estudos têm sido feitos com o intuito de estimar o valor de uso de amenidades ambientais. No entanto, são poucos os trabalhos desenvolvidos com praias que tratam da demanda e/ou valor dos serviços desse tipo de amenidade (Silberman et al., 1992). No Brasil não se encontrou nenhum trabalho publicado que trate da valoração econômica de praias. Encontrou-se apenas os trabalhos de Grasso et al. (1995) e Tognella (1995), que tratam da valoração econômica do ecossistema manguezal no Estado de São Paulo, e de Pessoa \& Ramos (1996), que trata da valoração econômica de ativos ambientais no Estado de Roraima.

Pearse (1968), apresenta uma abordagem para avaliar os recursos recreacionais para os quais não é possivel se estabelecer um preço. Assim, desenvolveu um trabalho com caçadores residentes na provincia de British Columbia - Canadá, a fim de avaliar o valor dos recursos de caça. A amostra era composta de 485 caçadores, estratificados em seis classes de renda. A análise procedeu-se da seguinte forma: os custos de viagem de cada caçador, inclusive custo do tempo gasto na viagem e outros gastos tal como licença para caçar etc., foram subtraidos do mais alto custo de viagem observado na sua classe de renda, para dar uma estimativa do excedente do consumidor ${ }^{6}$ de cada individuo. A média ponderada do excedente de todas as

6 Excedente do consumidor - é diferença entre o preço que o consumidor estaria disposto a pagar por um determinado bem ou serviço e o preço que ele realmente paga ao adquirir tal bem ou serviço (Pindyck \& Rubinfeld, 1994, p. 6). 
classes foi de US\$ 197 que, multiplicado pelo número total de caçadores residentes, resultou em US\$ 2.900.242. Este montante estima o valor total dos recursos de caça na área.

Gibbs (1974) critica o trabalho de Pearse enfatizando que a variável que deve ser usada como proxy do preço de um recurso é o custo no qual o visitante incorre no lugar onde estão sendo realizadas as atividades recreativas e não os custos de transporte como no modelo de Pearse. Seguindo esse raciocínio, ele estimou a função de demanda por visita à bacia do Rio Kissimmee na Flórida Central, procurando determinar o valor do recurso em função dos custos que eram incorridos no local. Esse valor foi obtido considerando a média das variáveis independentes (custo de viagem, renda familiar anual e quantidade de pessoas no grupo de excursão), exceto os custos no local. Em seguida a função de demanda estimada foi integrada do custo médio local (ou "preço" médio) até o custo máximo local (o mais alto custo no local observado). Os resultados obtidos apontam um valor médio de uso de US\$21,62 por pessoa, por dia. Usando o procedimento de Pearse, o valor de uso subiu para US\$143,20 por pessoa, por dia, ou seja, um montante 6,6 vezes maior. Como o custo médio de transporte foi 6,2 vezes maior que o custo médio diário no local, o autor chegou à conclusão que ambos os métodos podem ser usados para estimar o valor dos recursos.

Tobias \& Mendelshon (1991) estimaram o valor do eco-turismo para os turistas domésticos da Reserva Florestal Biológica Monteverde Claud na Costa Rica. Nesse estudo os autores aplicaram o método do custo da viagem (MCV). O MCV é um método de valoração indireto no qual os custos de transporte dos visitantes para a área de recreação são usados como proxy do preço da atividade recreacional, e a "quantidade de recreação comprada" é expressa pela taxa de visitação ${ }^{7}$. Esses dados são usados para estimar a

\footnotetext{
7 A taxa de visitaçāo representa, por exemplo, a quantidade de dias de visita ou a
} frequéência de visitas ao local de recreação, em um dado periodo de tempo. 
função de demanda, que permite calcular o excedente do consumidor da atividade, ou seja, o seu valor de uso. Os resultados mostraram que o valor anual da recreação doméstica está entre US\$97.500 e US\$ 116.200 na reserva estudada. No entanto, deve-se ressaltar que esse trabalho só leva em consideração os turistas domésticos. Não foram levados em consideração os turistas estrangeiros, o que subestima o valor dos beneficios do eco-turismo.

Com o objetivo de estimar o valor de uso da preservação da população de flamingo, bem como da vida silvestre, Navrud \& Mungatana (1994) realizaram um estudo no Parque Nacional do Lago Nakuru, Kenya. Eles utilizaram dados de uma amostra aleatória de 185 visitantes do parque em 1991, sendo 58 residentes e 127 turistas não residentes no local. Utilizaramse dois métodos alternativos para fazer as estimativas do valor de uso dos recursos, com o objetivo de verificar a validade dos mesmos. Esses métodos foram o MCV e o método de valoração contingencial (MVC). O MVC ê um método direto, no qual os consumidores revelam suas preferências através de respostas a perguntas sobre qual a sua disposição a pagar para usarem um determinado bem. Alternativamente, pode-se perguntar o nivel de compensação que eles estariam dispostos a aceitar para não comprometer a qualidade ambiental do local. Através de perguntas dessa natureza é possivel determinar, diretamente, o excedente do consumidor. Os resultados do trabalho indicam que, pelo método do custo de viagem, o valor recreacional médio por pessoa foi de US\$ 114 a 120 para os turistas não residentes, por ano. Já para os residentes, o valor de uso anual foi de US\$ 68 a 85 . No método da valoração contingencial estimou-se a disposição a pagar, de US\$ 73 , por ano, para os turistas não residentes e de US\$20, por ano, para os residentes. Segundo os autores, ambos os métodos apresentaram resultados razoáveis se comparado com outros estudos dessa natureza, sendo dificil dizer qual dos dois métodos melhor estima o valor de uso do bem, pois ambos diferem nas hipóteses e viéses potenciais. 
Grasso et al. (1995) estudaram o valor do ecossistema manguezal em Cananéia, Estado de São Paulo. Nesse estudo usaram o MCV e MVC para valorar os beneficios gerados para os turistas. Utilizando o $\mathrm{MCV}$, as estimativas foram de US\$33,7 milhões/ano. Com respeito à valoraçāo contingencial, os resultados obtidos apontam uma disposição média a pagar de US\$ 43,85 por mês, por pessoa. Expandindo o valor médio encontrado para a população de visitantes por ano, que é de 34.212 turistas, o valor anual agregado foi de US\$18 milhões para o ambiente manguezal.

Tognella (1995) desenvolveu um estudo para valorar as áreas de manguezal de Cananéia-SP, utilizando a técnica da avaliação de produtividade. O valor estimado foi de US\$17.093,15 para o periodo de oito meses de atividade pesqueira.

Pessoa \& Ramos (1996) desenvolveram um estudo com o objetivo de avaliar os recursos naturais em Roraima utilizando o MVC. Nessa aplicação utilizaram um modelo logístico para estimar a disposição a pagar dos individuos para preservar os ativos naturais da região. $O$ valor mediano estimado foi de $\mathrm{R} \$ 13,34$ por habitante, por mês. Considerando que são 72.500 habitantes o total de pessoas economicamente ativas, tem-se uma estimativa de $R \$ 967.150,00$ por mês para a preservação dos recursos naturais de Roraima.

Com relação à estimativa da demanda e/ou valor de uso das praias, são escassos os trabalhos na literatura, como foi enfatizado anteriormente. Dentre esses pode-se citar McConnell (1977), Silberman \& Klock (1988) e Bell \& Leeworthy (1990).

McConnell (1977) desenvolve um modelo supondo que a utilidade de um individuo depende da duração da excursão e da qualidade do lugar visitado e de outras variáveis. A principal variável utilizada para medir a qualidade das praias amostradas foi o número de individuos por acre (congestionamento). O levantamento dos dados foi feito através de entrevista 
direta com usuários de seis diferentes praias localizadas no sul da Ilha Rhode, nos Estados Unidos, a fim de determinar qual era a disposição a pagar pelo uso das praias com diferentes niveis de qualidade. Os resultados apontam que a disposição a pagar diminui com o aumento do nivel de congestionamento da praia.

Silberman \& Klock (1988) desenvolveram um estudo com o objetivo de quantificar os beneficios de recreação após a recuperação de praias, usando como exemplo as praias do Norte de New Jersey, nos Estados Unidos. Os beneficios da recuperação das praias foram estimados mediante perguntas diretas aos usuários sobre a disposição à pagar pelo uso da praia com e sem o projeto de recuperação. O método utilizado foi o da valoração contingencial (MVC), estimando-se tanto o valor de uso quanto o valor de existência de praias recuperadas. Os resultados apontaram que, sem o projeto, a disposição, média, a pagar era de US\$3,60 por pessoa, por visita. Com a implantação do projeto de recuperação, a disposição, média, a pagar dos usuários seria de US $\$ 3,90$ por pessoa, por visita, considerando apenas o valor de uso da amenidade.

A fim de estimar os beneficios totais gerados pela recreação nas praias, esses autores estimaram o número de visitas anuais às referidas praias, com e sem o projeto. Os valores dos beneficios encontrados foram: o valor de uso com o projeto foi de US\$14.136.424 por ano, o valor de uso sem o projeto foi de US\$ 8.454.517 por ano. Assim, o valor de uso líquido, isto é, o acréscimo no valor de uso foi de US\$5.681.907 por ano; acrescentando a este o valor de existência, chegou-se a um resultado de US\$ 6.679 .319 para o valor dos beneficios totais. Deve-se ressaltar que o valor de existência poderia ter sido muito maior se tivessem sido considerados os não-usuários das praias durante as entrevistas realizadas.

Bell \& Leeworthy (1990), estudando a demanda por recreação em praias, propõem uma abordagem alternativa para o método do custo de 
viagem. Para testar empiricamente essa nova abordagem, os autores estimaram uma função de demanda, por recreação, dos turistas que visitavam as praias da Flórida. A partir dessa abordagem, foi feita uma estimativa do valor de uso das praias (ou valor recreacional). Segundo esse modelo, a quantidade de dias na praia é função dos gastos na praia, dos custos de viagem, da renda dos individuos, de outras atividades durante a viagem e de outras caracteristicas sócio-econômicas.

Uma das diferenças em relação às outras abordagens do MCV é que no modelo de Bell \& Leeworthy a variável dependente é a quantidade de dias desfrutados na praia como recreação e não o número de viagens para a praia. E como proxy do preço foram utilizados os custos incorridos durante a permanência na praia em vez dos custos da viagem, como normalmente è considerado no $\mathrm{MCV}$. Uma outra diferença diz respeito à relação existente entre o número de dias que o turista permanece na praia e o custo de viagem. Para os autores, uma vez que os turistas estão decididos a realizar a viagem, as variáveis dias na praia e custo da viagem teriam uma relação direta, ou seja, um aumento nos custos de viagem aumentaria também a permanência dos turistas na praia. Isso porque muitos turistas fazem somente uma viagem por ano, então se eles deparam com um custo de viagem relativamente alto, tais turistas irão procurar obter a máxima satisfação e isto ocorrerá com o aumento no número de dias na praia. Uma vez que o turista encontra-se na praia, esse bem seria considerado como um bem comum, pressupondo os gastos na praia como o preço do referido bem, ou seja, a medida que o preço aumenta reduz-se a quantidade demandada.

De acordo com os resultados empiricos encontrados pelos autores, a relação descrita acima não foi rejeitada. Com relação à medida do valor de uso para os turistas que visitam as praias da Flórida, o valor encontrado foi de US\$33,91 por pessoa, por dia. Considerando que são aproximadamente 70 milhões o número de dias que os turistas gastam nas 
praias por ano, o valor de uso anual do recurso seria de US\$ 2,374 bilhões, isso sem considerar os residentes na Flórida. 


\section{REFERENCIAL TEÓRICO E METODOLÓGICO}

\subsection{Referencial teórico}

O objetivo deste item é o de facilitar o entendimento do problema que foi descrito no capitulo introdutório. Ele é constituído de dois sub-itens. Inicialmente, serão tratadas as imperfeiçōes de mercado que fazem com que o mercado falhe, e a associação dessas imperfeições com o recurso ambiental que será avaliado no presente estudo. $O$ sub-item seguinte trata da definição do valor de um bem e/ou recurso ambiental, definição esta que norteará esse trabalho.

\subsubsection{Fontes de ineficiência ${ }^{8}$ associadas ao recurso ambiental}

Para a teoria econômica neoclássica, sob determinadas condiçōes, os mercados são capazes de garantir, por si só, uma alocação eficiente dos recursos9. No entanto, devido a vários fatores, na prática, essa eficiência não é atingida. Em se tratando de recursos naturais e/ou ambientais, em geral, os mercados não são capazes de atingir a eficiência de mercado, ou seja, eles não racionam os recursos entre os consumidores e não fornecem informações corretas sobre a escassez relativa dos mesmos.

8 Maiores detalhes sobre fontes de ineficiência podem ser encontrados em Randall (1987), cap. 9.

9 Para um maior aprofundamento sobre esse assunto ver, por exemplo, Randall (1987), cap. 4 e cap. 5 . 
Os fatores que dificultam as operaçōes de mercado são conhecidos como imperfeições de mercado ou falhas de mercado. Alguns bens e recursos estão sujeitos a essas imperfeições de mercado devido às suas próprias caracteristicas e/ou a atenuação dos direitos de propriedade. No que diz respeito ao recurso ambiental que será avaliado nesse estudo, as principais fontes de ineficiência de mercado a ele associado são: nãoexclusividade, não rivalidade e bens congestionáveis.

\subsubsection{Não-exclusividade}

Diz-se que ocorre não-exclusividade quando não è possível excluir um individuo do consumo de um bem ou serviço. Isto porque o custo de exclusão dele seria muito maior que o beneficio recebido (Dixon 8 Shermann, 1990). Sem exclusão não é possivel obter um preço de mercado para o seu uso, e isso poderá resultar numa super-exploração do recurso em relação ao nivel eficiente, ocasionando uma degradação do mesmo. Poderá resultar também num baixo investimento no gerenciamento, conservação e capacidade produtiva, ou ainda numa sub-utilização do mesmo (Randall, 1987).

Segundo Randall (1987), são duas as causas da nãoexclusividade de um recurso, a saber:

- cultural e politica: as sociedades identificam alguns bens, serviços, amenidades e recursos que devem estar imunes às influências do mercado. Algumas coisas não devem ser vendidas ou compradas, mas são direitos inatos de cada um. Assim, a variável preço não deve ser utilizada na alocação/racionamento desses bens, visto que poderá afetar os valores culturais da população. Por exemplo, em muitas sociedades os parques ecológicos são identificados nessa categoria. Dessa forma elas não admitem que seja cobrado um preço de mercado para visitá-los; 
- natureza dos bens e recursos: devido às características básicas dos próprios bens e recursos não é possivel especificar precisamente os direitos de propriedade exclusivos, uma vez que os custos de especificar, assegurar e executar esses direitos seriam muito maiores que os beneficios que poderiam ser ganhos. Um dos exemplos mais tipico dessa não-exclusividade são os peixes nos oceanos. Para torná-los exclusivos, devem ser estabelecidos direitos de propriedades particulares nessas áreas. Para isso, os custos de implantação desses direitos seriam muito maiores que os beneficios gerados pelas mesmas.

Em se tratando das praias que são exploradas pela atividade turistica, parece que a razão da sua não-exclusividade está associada à primeira causa, cultural e politica, uma vez que, em principio, parece ser possivel, técnica e economicamente, estabelecer propriedades particulares nessas áreas.

\subsubsection{Não-rivalidade}

Em muitos casos, o consumo de um bem ou serviço por um determinado individuo reduz a quantidade disponivel desse mesmo bem ou serviço para um outro individuo na quantidade em que foi consumido. Os bens ou serviços que possuem essa caracteristica são estritamente competitivos (Dixon \& Sherman, 1990) e, por isso, são chamados de bens rivais.

Já os bens não-rivais são aqueles que, uma vez produzidos, estão disponiveis a todos os consumidores sem rivalidade. Ou seja, o consumo do bem ou serviço por um indivíduo não afeta a quantidade disponivel desse mesmo bem ou serviço para os outros individuos (Randall, 1987). Por exemplo, se um turista está observando as belezas naturais de uma praia, essas belezas disponiveis para aquele turista não serão diminuídas para os outros turistas. Outro exemplo, a descoberta de uma nova espécie ou de um 
novo cenário aumenta a utilidade de um individuo, mas isso não significa que irá reduzir a utilidade de um outro individuo por essas descobertas. Isto é, não há necessidade de se dividir a amenidade entre os consumidores, tendo cada um acesso à quantidade total disponivel. A não-rivalidade é conseqüência do atributo físico do bem ou serviço considerado e não o resultado de escolha institucional como a não-exclusividade pode ser.

Uma outra caracteristica dos bens não-rivais é a impossibilidade prática de se atribuir um preço eficiente para o uso dos mesmos (Ely, 1986). De acordo com Randall (1987), o preço de um bem não-rival seria igual ao valor marginal do bem ou serviço. No entanto, o valor marginal de um bem ou serviço difere de individuo para individuo, o que implicaria em preços diferenciados do bem ou serviço (preço discriminatório).

Além das dificuldades legais de se cobrar preços diferenciados dos consumidores, existe a dificuldade em se assegurar a revelação do verdadeiro valor marginal do bem por parte dos diferentes consumidores. Se o consumidor tiver de pagar o montante que ele voluntariamente declarar, então, é óbvio que haverá um incentivo para subdeclaração do valor. No limite, esse valor será igual a zero (Randall, 1987).

\subsubsection{Bens congestionáveis}

Existem alguns bens ou serviços que se comportam como bens não-rivais até certo ponto, ou seja, até atingir o ponto de sua capacidade máxima de carga. Depois desse ponto passam a comportar-se como se fossem rivais. Os bens ou serviços que possuem essas características são chamados de bens que congestionam ou bens congestionáveis (Dixon \& Sherman, 1990; Randall, 1987).

Segundo Randall (1987), as caracteristicas dos bens que congestionam são: a) podem ser apreciados/utilizados por muitos individuos, mas estão sujeitos a uma restrição de capacidade; caso essa restrição não seja 
obedecida, haverá uma redução na satisfação dos consumidores desse bem; b) o custo fixo de fornecimento do bem é muito maior do que o custo marginal de adicionar um usuário até que a capacidade máxima seja atingida, após esse ponto, o custo marginal torna-se muito maior que o custo fixo. Muitas amenidades ambientais possuem caracteristicas de bens que congestionam, como, por exemplo, as praias usadas pelos turistas. 10

Essas imperfeições de mercado causam distorções no preço de mercado, de modo que este último não reflete o verdadeiro valor do bem ou serviço. Isso faz com que os beneficios gerados sejam freqüentemente ignorados ou grosseiramente subestimados (Dixon \& Shermann, 1990 e 1991).

\subsubsection{Definição do valor de um recurso ambiental}

O termo valor de um recurso ambiental nesta dissertação será entendido como sendo a expressão monetária dos beneficios obtidos de sua provisão do ponto de vista pessoal de cada indivíduo (Belluzzo Jr., 1995).

A atual literatura da economia ambiental admite que existem três tipos distintos de valores que compõem o valor econômico total do meio ambiente, a saber:

- valor de uso: refere-se ao valor atribuído pelos individuos pela participação numa determinada atividade, isto é, pelo uso atual da amenidade ambiental (Adamovicz, 1991).

- valor de opção: diz respeito a disposição a pagar, dos individuos, para conservar um determinado recurso ou amenidade ambiental que poderá ser

10 A capacidade de carga (carrying capacity) de um recurso turístico ê o número máximo de visitantes que uma área pode receber, sem provocar alterações ao meio. Estudos desenvolvidos no sul da França apontam um total de 800 pessoas por ha/dia na área da Grande Motte como a capacidade de carga ideal do local. No entanto, esse valor varia dependendo do tipo e tamanho da área, do solo, da topografia, etc.(Ruschman, 1994). 
usado no futuro e cuja substituição seria dificil ou impossivel (Krutilla, 1967). Assim, o valor de opção expressa também uma preocupação com as gerações futuras.

- valor de existência: quando os individuos obtêm benefícios pelo simples conhecimento de que determinada amenidade ambiental ou certa espécie existe, sem que haja a intenção de apreciá-las ou usá-las de alguma forma. Esse valor é conhecido na literatura como valor de existência e independe do uso direto, seja no presente ou no futuro (Dixon \& Sherman, 1991).

Assim sendo, os bens e/ou recursos ambientais podem gerar beneficios tanto do uso direto (mensurados pelo valor de uso) como do uso indireto ou uso passivo (mensurados pelo valor de opção e/ou pelo valor de existência).

\subsection{Métodos de valoração de áreas de recreação}

Como já foi abordado anteriormente, a teoria neoclássica "tradicional" é incapaz de captar as influências geradas pelas falhas ou imperfeições de mercado na determinação dos preços dos bens e serviços. Assim sendo, as funções de demanda por um recurso ambiental são mensuradas através de evidências indiretas, ou seja, utilizando um mercado hipotético para as amenidades ambientais.

Para se fazer uma estimativa dos diferentes itens que compõem o valor econômico de amenidades ambientais são utilizadas principalmente duas abordagens, uma direta e a outra indireta. O principal método direto utilizado è o Método da Valoração Contingencial (MVC) e o indireto é o Método do Custo de Viagem (MCV).

Assim, este item tem como objetivo expor os dois métodos de valoração de áreas de recreação que foram citados anteriormente, para que, 
em seguida, seja feita a escolha daquele que se adeque melhor para resolver o problema proposto no capitulo introdutório.

\subsubsection{Método da valoração contingencial ${ }^{11}$}

O método da valoração contingencial consiste em realizar entrevistas com individuos a fim de que possam revelar sua valoração pessoal de bens "sem preço" usando um mercado hipotético (Cummings et al., 1986). Para isso, geralmente, faz-se a aplicação de questionários a uma amostra da população de usuários da amenidade. Além das informações referentes ao valor de uso (uso ativo da amenidade), ao valor de opção e ao valor de existência (referem-se ao uso passivo da amenidade), ou seja, qual seria a disposição à pagar, deles, para usarem essas amenidades no presente ou possibilidade de uso futuro ou ainda para simplesmente garantir sua existência, também são coletadas informaçōes sobre atitudes, variâveis sôcioeconômicas, etc.

Apesar deste método ser bastante utilizado atualmente para atribuir valores às amenidades ambientais, vârios autores têm enfatizado a existência de alguns problemas de mensuração associados ao uso do mesmo (dentre eles pode-se citar Schulze et al., 1981; Hufschmidt et al., 1983; Cummings et al., 1986). Esses autores classificam esses problemas como: viés estratégico, viés de informação, viés de instrumento e viés hipotético.

$O$ viés estratégico ocorre quando os individuos percebem que suas respostas podem influenciar as decisões de tal forma que os seus custos irão diminuir ou seus benefícios irão aumentar em relação ao resultado esperado num mercado normal. Por exemplo, se um individuo é perguntado sobre sua disposição a pagar por uma melhoria na qualidade visual de uma

11 Para uma melhor e mais detalhada discussão sobre este método de valoração de bens ambientais ver, por exemplo, Cummings et al. (1986). 
área próxima de sua residência e ele sabe que ele não irá pagar, mas que o projeto será financiado por outras pessoas, então sua disposição a pagar será muito maior; caso contrário, se ele tiver que pagar, então o valor que ele irá declarar será muito menor.

$O$ viés de informação pode resultar da maneira como as alternativas são apresentadas aos entrevistados. Informações detalhadas podem ser necessárias para expor o que se quer valorar. Isto é essencial devido à natureza hipotética do método. Assim, o viés pode ser reduzido pelo uso do visual, como por exemplo fotografias, especialmente se os individuos não conhecem a amenidade que estả sendo valorada.

Um outro tipo de viés associado ao MVC é o viés de instrumento, que pode resultar da escolha do método usado para coletar a disposição a pagar. Por exemplo, algumas taxas são mais onerosas que outras e o uso delas influenciará a resposta dos entrevistados. Esse viés também pode resultar dos tipos de perguntas que são feitas aos entrevistados. Assim, elas devem ser elaboradas de modo que o entrevistador não induza uma resposta do entrevistado.

E por último, mas não menos importante, è o viés hipotético. Esse é inevitável num processo em que o comportamento de um mercado não é observado, principalmente se os entrevistados têm pouca ou nenhuma familiaridade com a amenidade que está sendo valorada.

Um outro problema do MVC está relacionado com a restrição orçamentária dos entrevistados e com relação à existência de recursos substitutos. Em alguns casos, os entrevistados não levam em consideração essa restrição no momento de responder sobre sua disposição a pagar, por se tratar de uma situação hipotética. Com relação aos recursos substitutos, por não serem usados ativamente, nem sempre são levados em consideração. Assim, o valor de uso passivo dos recursos estará consideravelmente deturpado, pois segundo a teoria econômica, quanto maior o número e a 
qualidade dos substitutos disponiveis menor será a disposição a pagar dos consumidores (Desvousges et al., 1993). Além dos problemas acima citados, uma outra limitaçāo associada a esse método é o alto custo necessário para sua realização.

Entretanto, isso nāo quer dizer que os resultados obtidos através do MVC não serão ou não poderão ser usados. Em muitos casos, não existem técnicas alternativas de valoração, sendo esse o único meio disponivel para produzir estimativas de valores (Dixon \& Shermann, 1990).

\subsubsection{Método do custo de viagem}

O método indireto mais utilizado para valoração de atividades recreacionais é o mêtodo do Custo de Viagem. Basicamente, o MCV usa os custos incorridos pelos individuos, quando viajam para um determinado local de recreação, como substituto do preço do bem ou serviço que é explorado pela referida atividade (Tisdell, 1991). O método consiste em estimar os beneficios gerados por uma determinada atividade recreacional, com base nos custos incorridos para se utilizar as amenidades que são exploradas pela referida atividade.

Para se estimar os beneficios torna-se necessärio, em primeiro lugar, fazer uma regressão múltipla utilizando-se individuos ou zonas ${ }^{12}$ como observações. Este tipo de desagregação das observações irá depender, basicamente, de como está sendo especificada a variável dependente. Caso a variável dependente seja definida como sendo a freqüência de visita ao atrativo, aconselha-se a trabalhar com os dados agregados por zonas. Isso porque nos casos onde o local de recreação é longe o suficiente para que

12 O método do custo de viagem foi originalmente concebido em termos de zonas concêntricas ao redor do atrativo recreacional, ou seja, feita a localização geográfica do local, a área circunvizinha era dividida em regiões de acordo com a distância ao atrativo. No entanto, agora é comum o uso da jurisdição politica, como por exemplo paises, estados, cidades, etc., para definir uma zona (McConnell, 1985). 
ocorra somente uma visita por ano, seria muito dificil medir o efeito da distância (Freeman III, 1979).

Brown et al. (1983) afirmam que a estimativa de uma função de demanda por recreação com observaçōes individuais será viesada, pois não leva em consideração o fato de que somente uma pequena parte da população das zonas mais distantes participa da atividade. Conseqüentemente, também produzirá uma estimativa viesada do excedente do consumidor. Para solucionar estes problemas, os autores sugerem que a variável dependente, freqüência de visita, seja expressa em termos per capita.

Na utilização do MCV, Freeman III (1979) afirma que alguns procedimentos gerais devem ser seguidos:

1. a área adjacente ao local da recreação deve ser dividida em zonas com o propósito de mensurar os custos de viagem de cada zona ao local de recreaçāo;

2. no local de recreação uma parte dos visitantes é amostrada com a finalidade de determinar as zonas de origem ou, no caso de observações individuais, os locais de procedência dos visitantes;

3. define-se o que será considerado como taxa de visitação como, por exemplo, dias de visita per capita ou freqüência de visita. Em seguida, calcula-se essa taxa para cada zona de origem;

4. calcula-se o custo de viagem da zona de origem (ou do local de procedência) ao local de recreação'13;

5. em seguida faz-se uma regressão da taxa de visitação contra os custos de viagem e outras variáveis sócio-econômicas;

13 Em geral, o custo de viagem, que também inclui o custo de oportunidade do tempo, é calculado em $\$ / \mathrm{km}$. 
6. a visitação total observada representa apenas um ponto sobre a curva de demanda para o local de recreação, isto é, o ponto que representa a quantidade demandada quando o preço de entrada no local é zero; e,

7. finalmente, para encontrar os outros pontos sobre a curva de demanda, pressupõe-se que os visitantes responderiam ao aumento no preço de entrada do local da mesma forma que respondem ao aumento nos custos de viagem.

Em resumo, o método baseia-se na aplicação de questionários aos usuários da área de recreação, com a finalidade de coletar informações sobre: custos de viagem, taxa de visitação, caracteristicas sócio-econômicas, etc. A partir desses dados, estima-se a curva de demanda e o excedente do consumidor. Este último representa uma estimativa do valor econômico do local em questão.

Obviamente, quando é feita a opção de trabalhar com observações individuais, alguns dos procedimentos que foram descritos acima tornam-se desnecessários. Algebricamente, os procedimentos acima descritos podem ser assim resumidos:

Para cada zona (i), estima-se uma função do tipo:

$$
V_{i}=f\left(M_{i}, S_{i}, C_{i}\right) \quad(i=1,2, \ldots, \mathrm{n})
$$

em que:

$$
\begin{aligned}
& V_{i}=\text { a taxa de visitação da zona } \mathrm{i} ; \\
& M_{i}=\text { a renda média na zona } \mathrm{i} \\
& S_{i}=\text { as outras variáveis sócio-econômicas; } \mathrm{e} \\
& C_{i}=\text { os custos da viagem da zona i até o local de recreação. }
\end{aligned}
$$

Pressupondo-se preço zero para visitar o local, o total de visitas será dado por: 


$$
V=\sum_{i=1}^{n} V_{i}
$$

em que:

$$
V=\text { a soma total da taxa de visitação ao local de recreação. }
$$

De posse da função de demanda por recreação, o valor de uso do local atribuido pelos visitantes, segundo McConnell (1985) pode ser estimado da seguinte forma:

$$
V_{\text {uso }}=\sum_{i=1}^{n} \int_{c i}^{c i^{*}} V\left(M_{i}, S_{i}, C_{i}\right) d c
$$

em que:

$$
\begin{aligned}
c i= & \text { ao custo corrente de viagem da i-ésima zona ao local de } \\
& \text { recreação; e, } \\
c i^{*}= & \text { ao preço de restrição da i-ésima zona, ou seja, o preço } \\
& \text { máximo para o qual a demanda é nula. }
\end{aligned}
$$

\subsubsection{Problemas enfrentados em decorrência do uso do MCV}

Apesar do MCV ser reconhecido como um dos melhores métodos para valorar atividades recreacionais, o seu uso pode gerar uma série de problemas que podem ser decorrentes de falhas nas pressuposições do método ou de uma especificação deficiente do modelo. Segundo Tisdel (1991) os principais problemas do MCV são os seguintes:

1. não-homogeneidade de atributos relevantes da população de diferentes zonas. O MCV assume que os individuos, na média, possuem a mesma forma de demanda por visita para um determinado atrativo;

2. implicitamente, pressupõe-se que a visitação do local tem um propósito único. No entanto, na prática, as viagens possuem vários objetivos; 
3. pressupõe-se que os individuos não obtêm utilidade durante o processo de viagem;

4. os dados referentes a uma determinada área são limitados a uma amostra. A questão é saber se os dados são representativos da população. Por exemplo, se a freqüência de visita é sazonal e os dados foram coletados num periodo de alta estação e a demanda projetada para ser demanda anual, esta será superestimada. O oposto ocorre se os dados forem coletados na baixa estação;

5. existe o problema de escolha da forma apropriada da função para ajustar aos dados; e,

6. freqüentemente o valor econômico de um recurso ambiental não depende apenas das visitações. Há tambẻm os beneficios externos, que são oriundos do valor de opção e/ou do valor de existência. Nesse caso, o MVC é mais apropriado para mensurar esses últimos.

Por outro lado, o MCV não apresenta somente problemas, exibindo algumas vantagens em relaçāo aos demais. Adamowicz (1991), aponta que as principais vantagens do MCV são: a) ele estima valores usando dados cross-section, da mesma forma que a abordagem econômica "tradicional" para estimativa de função de demanda e valoração de bens; b) permite ao pesquisador a formulação de modelos de comportamento que podem ser testados; permite também a formulação de hipóteses com relação aos parâmetros dos respectivos modelos que podem ser testadas.

\subsubsection{Especificação da função e das variáveis}

Conforme foi abordado anteriormente, um dos problemas a serem enfrentados na formulação da demanda por recreação, dentre outros, é a escolha da forma funcional, bem como das variäveis explicativas do modelo. Em estudos dessa natureza, a escolha das variáveis e da forma funcional deve 
ser feita levando-se em consideraçāo a teoria econōmica e estudos anteriores de demanda por recreação (Ziemer et al., 1980).

Os pesquisadores devem ter duas preocupações com relação à forma funcional: a) diferentes formas funcionais podem gerar distintas estimativas do excedente do consumidor ${ }^{14}$; b) as diferentes formas das funções implicam em diferentes relaçōes entre os excedentes Marshallianos e Hicksianos (Backstael \& McConnell e Henemann15, citados por McConnell, 1985).

No que diz respeito à escolha das variáveis, de acordo com a teoria neoclássica, as equações de demanda podem ser expressas como sendo a quantidade consumida de um bem em função do preço do bem, preço dos bens substitutos e/ou complementares, renda e outras variáveis, geralmente sócio-econômicas.

Seguindo a estrutura neoclássica, a função demanda por recreação relaciona a taxa de visitação do recurso ou atrativo, com os custos de viagem e outras variáveis relevantes, isto é, variáveis sócio-econômicas. Alèm disso, deve-se levar em consideração os custos de viagens para atrativos alternativos (os quais são usados como proxy do preço da visita para atrativos substitutos) e os custos incorridos no local da recreação referentes a hospedagem, alimentação, eventos sociais, etc.

Assim, a função demanda pela atividade recreacional, de uma maneira geral, pode ser expressa da seguinte forma:

14 Com relação a essa preocupação, ver, por exemplo, o trabalho de Ziemer et al. (1980).

15 BACKSTAEL, N. E.; MCCONNELL, K. E. Calculating equivalent and compensating variation for natural resource facilities. Land Economics, v. 56, n. 1, p. 56-63, feb. 1980 .

HENEMANN, W. M. Measuring the worth of natural resource facilities: comment. Land Economics, v.56, n. 2, p. 482-486, may. 1980. 


$$
Q=f\left(P, X, P_{S}, P_{C}\right)
$$

em que:

$$
\begin{aligned}
Q= & \text { a quantidade demandada do atrativo ou taxa de visitação ao } \\
& \text { atrativo; } \\
P= & \text { ao custo de viagem ao atrativo; } \\
X= & \text { a um vetor das variáveis sócio-econômicas (tais como renda, } \\
& \text { idade, grau de escolaridade, etc.); } \\
P_{S}= & \text { ao custo de viagem aos locais substitutos; e, } \\
P_{C}= & \text { ao preço dos bens ou serviços complementares. }
\end{aligned}
$$

A determinação dos gastos que irão ou não fazer parte da variável custos de viagem não é tão simples, como parece à primeira vista. Segundo McConnell (1985), existem dois tipos de custos que devem ser levados em consideração: os custos que são realmente incorridos por ocasião da viagem (como, por exemplo, passagens, pedágios, etc.) e os custos de oportunidade do tempo.

Com relação aos gastos que devem compor os custos incorridos na viagem, a literatura não deixa muito claro quais são os gastos relevantes que devem ser incluidos. Sabe-se que tanto o fato de excluir gastos relevantes como o de incluir gastos sem relevância, poderá ocasionar estimativas viesadas dos parâmetros da equação, bem como da estimativa do excedente do consumidor (McConnell, 1985).

Matematicamente, esse mesmo autor mostra o problema da seguinte forma. Supondo-se a função de demanda verdadeira ser do tipo descrita na eq. (5):

$$
Q=\beta_{o}+\beta_{1} c+\text { erro }
$$

em que:

$$
Q=\text { a quantidade demandada de recreação; }
$$


$c=$ ao custo de viagem; $\mathrm{e}$,

$\beta_{o}$ e $\beta_{1}$ são os parâmetros a serem estimados.

Integrando a eq. (5) do ponto $c$ igual a zero até o ponto $c$ igual a $\beta_{o} / \beta_{1}$ encontra-se a área sob a curva de demanda16 (ver eq. 6) como sendo:

$$
b=-\frac{\beta_{0}^{2}}{2 \beta_{1}}
$$

Agora suponhando-se que o custo de viagem seja $c^{*}$ (em que, $c^{*} \hat{e}$ igual a uma proporção de $c$, ou seja, $c^{*}=\theta c$ ). Assim, a estimativa do novo coeficiente de regressão será $\beta_{1} / \theta$. A equação de demanda passa a ser escrita da seguinte forma:

$$
Q=\beta_{o}+\frac{\beta_{1}}{\theta} c^{*}+\text { erro }
$$

Integrando-se a eq. (7) encontra-se o seguinte valor para a área sob a curva da demanda:

$$
b^{*}=-\frac{\beta_{0}^{2}}{\frac{2 \beta_{1}}{\theta}}
$$

Assim, caso ocorra uma subestimativa dos custos de viagem, irá provocar uma subestimativa no coeficiente de regressão e como conseqüência também do excedente do consumidor, da mesma proporção que os custos foram subestimados. Ou seja, caso os custos de viagem sejam subestimados em $25 \%$, o excedente do consumidor também será reduzido em $25 \%$. Caso haja uma superestimativa dos custos de viagem, ocorrerã como conseqũência uma superestimativa do excedente do consumidor.

16 O sinal negativo na fórmula de cálculo do excedente do consumidor $(b)$ é para tornar positivo o valor de $b$, visto que o valor de $Q$ será sempre positivo e o do $\beta_{1}$ será sempre negativo. 
Quanto ao custo de oportunidade do tempo, reconhece-se a sua participação nos custos totais de visitação de um determinado local de recreação. McConnell (1985) afirma que existem dois aspectos que devem ser considerados aqui. Em primeiro lugar, o problema de sua mensuração. Em segundo lugar, qual o tempo que deve ser medido (o tempo no local, o tempo de viagem ou ambos). Como no caso dos custos discutidos anteriormente, aqui também poderá ocorrer problemas na estimação dos parâmetros, caso esses custos não sejam levados em consideração.

No caso do turismo, parece razoável assumir que o tempo a ser considerado é somente o tempo de viagem, já que como os turistas estão gozando férias de seus trabalhos, não iriam utilizar parte do seu tempo no trabalho, mas sim em lazer. Já o custo do tempo de viagem deve ser incluído, pois supõe-se que os turistas não obtêm utilidade durante o tempo de viagem, mas somente no local que será visitado.

Além dessas variáveis proxy dos preços dos bens, de acordo com a teoria neoclássica as equações de demanda devem incluir os preços dos bens substitutos e/ou complementares. Assim, os custos de viagem para locais substitutos têm importantes papéis na estimativa de equaçōes de demanda por recreação.

Levando em consideração a exposição feita sobre os dois principais métodos de valoração de áreas de recreação, pode-se perceber que embora o método da valoração contingencial possa ser usado para estimar os três tipos de valores mencionados anteriormente, é um método ainda bastante questionado sobre sua real validade. Outro ponto negativo deste método é que requer um alto custo para obtenção dos dados. Já o método do custo de viagem, embora não possa ser usado para estimar os três tipos de valores já referidos pode ser usado para estimar a função de demanda e, a partir dela, o valor de uso das amenidades, bem como ê um método com boa aceitação no meio acadêmico. Assim, neste estudo optou-se por trabalhar com esse método 
indireto de valoração, visto que a preocupação maior é estimar a função de demanda por turismo e o valor de uso dessas amenidades, no litoral cearense. Além disso, segundo Adamowicz (1991) esse método é mais confortável para os economistas. Visto que, como em quase todas as análises econômicas tradicionais, ele emprega informaçōes sobre o comportamento atual e tenta construir modelos que representem esse comportamento.

\subsection{Aplicação do método do custo de viagem}

Estudos que tratam da demanda recreacional têm usado como variável dependente a freqüência de visitação ao atrativo recreacional. No entanto, estando trabalhando com a atividade turistica, a freqüência de visitaçāo às praias por ano não poderá ser usada como variável dependente. Isso porque os turistas, geralmente, residem em locais distantes, fazendo com que não ocorra variação nessa taxa entre os individuos amostrados. Geralmente, eles viajam no seu periodo de férias e isto só ocorre uma vez no ano.

Assim, procurando solucionar esse problema, optou-se por utilizar uma modificação do método de custo de viagem proposto por Bell \& Leeworthy (1990). Neste caso, a variável dependente é o número de dias gastos na praia pelos turistas e não a freqüência de visitação como nos modelos tradicionais.

A utilização da quantidade de dias gastos na praia pelos turistas, como variável dependente, além de solucionar o problema acima levantado, permite que seja utilizado o método do custo de viagem com observações individuais (MCVI). Isso só é possivel visto que parece não haver relação entre a quantidade de dias que os turistas permanecem na praia e a distância viajada. Além disso, o MCVI produz estimativas do valor de uso muito mais próximas do verdadeiro excedente do consumidor, quando se compara as 
estimativas desse valor utilizando o método do custo de viagem com observações por zonas, isto ê, o MCV tradicional (Willis \& Garrod, 1991).

No que diz respeito às variáveis independentes da função de demanda, a literatura não é clara sobre quais são as variâveis que deveriam ser escolhidas para fazer parte do modelo, nem como essas variáveis devem ser mensuradas. Assim, para realizaçāo deste estudo, tomar-se-á por base as variáveis utilizadas nos trabalhos de Gibbs (1974), Bell \& Leeworthy (1990) e Navrud e Mungatana (1994). Dessa forma, o preço da recreação, isto é, os custos de viagem para as praias, renda familiar, outras variáveis sócioeconômicas tais como idade, sexo, nível educacional, e variáveis qualitativas serão incluidas como variáveis independentes no modelo de regressão.

Neste trabalho, a estimativa dos parâmetros da equação de demanda por turismo no litoral cearense foi realizada através da técnica da regressão linear múltipla. A referida equação foi formulada da seguinte maneira:

$$
Q=f(P, R, I, S, E, X)
$$

em que:

$Q=$ número de dias gastos na praia por ano;

$P=$ custos de viagem;

$R=$ renda anual familiar;

$I=$ idade;

$S=$ sexo (variável dummy);

$E=$ grau de escolaridade; $\mathrm{e}$,

$X=$ vetor de outras variáveis qualitativas (expostas a seguir).

Conforme já foi ligeiramente abordado, a função de demanda pode ser utilizada na valoração das amenidades ambientais. Ou seja, de posse 
da função de demanda e do preço do bem ou serviço é possivel estimar os beneficios do mesmo para a sociedade.

Segundo Richards \& Brown (1992), o beneficio econômico liquido de um bem ou serviço ambiental é tipicamente estimado como o excedente do consumidor, ou seja, a disposição a pagar dos consumidores por um bem ou serviço acima do que eles pagam efetivamente. Matematicamente, o excedente do consumidor (ou valor de uso) é equivalente a área que fica abaixo da curva de demanda do bem ou serviço e acima do preço pago pelo mesmo, isto é, dos custos de viagem. Essa área será estimada usando o método da integração na função de demanda do ponto representado pelo preço pago efetivamente pelos consumidores (turistas) até o ponto que representa o preço máximo, ou seja, disposição a pagar máxima dos consumidores.

A seguir são apresentadas as variáveis explicativas que foram utilizadas no modelo de regressão para estimar a função de demanda por turismo.

\subsubsection{Custo de viagem}

A variável custos de viagem (CV) foi obtida somando os custos de oportunidade do tempo de duração da viagem (CTe) com os gastos por dia do turista durante a sua permanència em Fortaleza (Gind). Neste item, estão incluidas as despesas de alimentação, hospedagem, souveniers, etc. Algebricamente o $C V$ pode ser apresentado da seguinte maneira:

$$
C V=C T e+\text { Gind }
$$

As despesas de locomoção (custos de transporte) foram consideradas como uma outra variâvel dependente (esta será exposta mais adiante), com o intuito de captar qual dos dois custos, de viagem ou o de transporte, exercia maior influência sobre a quantidade demandada de praia. 


\section{- Custo de oportunidade do tempo (CTe)}

Conforme foi enfatizado anteriormente, o custo de oportunidade do tempo tem importante papel nas funçōes de demanda por um local de recreação. No entanto, a forma como este deve ser abordado ainda não está devidamente solucionada na literatura disponivel. Atualmente, são sugeridas duas abordagens principais. $\mathrm{Na}$ primeira, o custo do tempo é considerado como uma variável independente no modelo. Na segunda, o custo do tempo é somado aos gastos individuais para gerar o custo de viagem. Essa última é mais comum na literatura.

A mensuração do custo de oportunidade do tempo usa uma proporção da taxa de salário dos individuos. Segundo McConnel \& Strand (1981) a escolha dessa proporção é arbitrária e independente da população amostrada. Vários estudos têm sugerido uma proporção em torno de um terço a um quinto do salário mensal dos turistas. Tomando por base os trabalhos realizados recentemente por Navrud \& Mugatana (1994) e Richards \& Brown (1992), o custo de oportunidade do tempo de viagem foi calculado como sendo o produto entre o tempo gasto na viagem e a taxa de salário temporal. Assim, o custo médio do tempo gasto na duração da viagem, do local de procedência até a cidade de Fortaleza, será obtido pela seguinte fórmula:

$$
C T e=\operatorname{Tv} x\left(\operatorname{Ts} \times \frac{1}{3}\right)
$$

em que:

$T v=$ tempo de viagem, em horas;

$T s=$ taxa de salário temporal, em reais por hora

A multiplicação da taxa de salário pelo fator $1 / 3$ é para indicar que o valor do tempo gasto em férias é menor que a taxa de salário geral (Navrud \& Mugatana, 1994; Smith \& Kaoru, 1990; Cesario, 1976). Esse fator 
de ponderação do salário pode variar de individuo para individuo, mas neste estudo foi assumido como sendo constante para todos os individuos.

O tempo de duração da viagem foi calculado de acordo com a disponibilidade dos dados e do tipo de transporte utilizado pelos turistas. Quando o tipo de transporte utilizado tinha sido ônibus, carro, moto ou trem, esse tempo foi obtido da seguinte forma:

$$
T v=\frac{d}{V}
$$

em que :

$$
\begin{aligned}
& d=\text { distância percorrida, em quilômetro } 17 \\
& V=\text { velocidade média do transporte, em quilômetro por hora } 18
\end{aligned}
$$

No caso dos turistas utilizarem o aviāo para se deslocar do seu local de procedência até a cidade de Fortaleza, o tempo de duração da viagem foi admitido ser igual ao tempo previsto de vôo.

Sabe-se que tanto o número de dias de trabalho por ano como o número de horas de trabalho por dia podem variar entre os individuos. Porém, para efeito de estudo, considera-se como sendo os mesmos para todos os individuos entrevistados.

Dessa forma, a taxa de salário temporal foi derivada da renda mensal, assumindo que os turistas trabalham em média 250 dias no ano ${ }^{19}$, cada dia com duração de oito horas. Assim, a taxa de salário temporal foi obtida da seguinte maneira:

\footnotetext{
17 A distância que foi considerada foi a do local de procedência até o local onde se encontra o atrativo.

18 Foi assumido que a velocidade média de um ônibus é $60 \mathrm{~km} / \mathrm{h}$ e de um carro é 80 $\mathrm{km} / \mathrm{h}$

19 Foi admitido um ano com 365 dias. Destes, foram subtraidos os sábados (52), domingos (52) e feriados nacionais (11), num total de 115 dias. Assim, chegou-se a um total de 250 dias de trabalho, por ano, em média.
} 


$$
T s=\frac{R}{h}
$$

em que:

$$
\begin{aligned}
& R=\text { renda mensal, em reais; } \\
& h=\text { número de horas de trabalho mensal, em horas }
\end{aligned}
$$

\section{- Gastos individuais por dia (Gind)}

Neste último sub-item dos custos de viagem são incluidos os custos, médios, incorridos pelos turistas por cada dia de permanência no Estado do Ceará. Esses custos incluem hospedagem, alimentação, transporte (ônibus coletivo e/ou taxi), bebida, etc.

Com relação a variâvel custos de viagem $(C V)$, espera-se que a mesma comporte-se como argumenta a teoria econômica, ou seja, que o preço do bem varie inversamente com a quantidade consumida (número de dias que o turista permanecerá no Ceará). Assim, um aumento (redução) nos custos de viagem deve ocasionar uma reduçāo (aumento) na permanēncia dos turistas no Ceará.

\subsubsection{Custo de transporte}

Para os cálculos dos custos de transporte (CTr̂, McConnell (1985) e Tobias \& Mendelshon (1991) sugerem a utilização da fórmula apresentada a seguir, levando em consideração o tipo de transporte utilizado pelo turista para chegar até o local do atrativo.

$$
C T r=d x c t
$$

em que:

$$
\begin{aligned}
& d=\text { distância percorrida, em quilômetro; } \\
& c t=\text { custo de transporte, em reais por quilômetro }
\end{aligned}
$$


No entanto, devido a não disponibilidade de dados dessa natureza para as rodovias brasileiras, para o cálculo de custo de transporte (ct, em $\mathrm{R} \$ / \mathrm{km}$ ) foi utilizada a fórmula publicada mensalmente pela revista Transporte Moderno (1995). Assim, quando o tipo de transporte utilizado pelo turista tinha sido carro, o custo de transporte $(c t)$ foi calculado como segue:

$$
c t=\left(\frac{387,75}{X}\right)+0,1278
$$

em que:

$$
X=\text { utilização média mensal, em quilômetro } 20
$$

Quando o tipo de transporte utilizado pelo turista tinha sido ônibus ou avião, o custo de transporte foi admitido ser igual ao preço pago pelas respectivas passagens.

Para a variável custo de transporte, espera-se que varie diretamente com a permanência dos turistas, ou seja, uma vez que o turista decidiu fazer a viagem, um aumento nesses custos estimulará o turista a fazer viagens mais longas para compensar os gastos.

\subsubsection{Variáveis sócio-econômicas}

As variáveis sócio-econômicas consideradas relevantes na estimativa da função de demanda por turismo são: renda familiar anual, idade e grau de escolaridade. Os sinais esperados para os parâmetros destas variáveis são os seguintes: i) para as variáveis renda familiar e nivel de escolaridade, positivo; e, ii) negativo para a idade. No primeiro caso espera-se que as pessoas com nivel de renda mais elevado tenham uma maior possibilidade de viajar para locais mais distantes. No que diz respeito ao nivel

${ }^{20}$ Foi assumido que a utilização média de um veículo é de $20.000 \mathrm{~km} /$ ano 
escolaridade, acredita-se que pessoas com um maior grau de instrução valorizem mais a atividade de recreação (ceteris paribus). Com relação à idade, espera-se que os mais jovens tenham um maior desejo de aventura, fazendo com que viajem para locais mais distantes e pouco conhecidos por eles. Aliado a isto existe uma maior atração dessas pessoas pelo contato com a natureza.

\subsubsection{Variáveis comportamentais e dummy}

Neste estudo, considera-se as seguintes variáveis nesta categoria: estado civil, sexo, com quem está viajando, número de viagens à Fortaleza nos últimos dois anos, se viaja por agência e os motivos da viagem para o Ceará. Tambêm inclui-se nesta categoria de variável a quantidade de dias que os turistas permanecem na praia, utilizada como variável dependente na função de demanda por turismo.

Quanto a inclusão das variáveis sexo e estado civil no modelo, espera-se que seja possivel captar uma demanda por turismo diferenciada entre as pessoas do sexo masculino e feminino, bem como entre solteiros e casados. Com relação à variâvel com quem está viajando (sozinho ou com familiares), espera-se que quem viaja sozinho permaneça menos tempo em Fortaleza. No que diz respeito ao número de viagens a Fortaleza, espera-se que os turistas, à medida que aumentam o número de viagens a um determinado atrativo turistico, diminuam a sua permanència neste local.

Para a variável que procura captar qual influência da viagem ser organizada ou não por uma agência de viagens sobre a permanência média do turista no Ceará, espera-se que tenha sinal negativo, ou seja, quando a vigem for organizada por uma agência, o turista tenda a permanecer menos tempo no Cearā, uma vez que, geralmente, essas agências trabalham com pacotes com um número de dias da viagem prê-determinado, o que poderá induzir os turistas na determinação da duração da mesma. Com relação a variável motivo da viagem, espera-se que a mesma tenha um sinal positivo, isto é, 
quem viaja por motivo de lazer/recreio ou para visitar parentes/amigos, tenha influência direta sobre a permanência no Ceará.

\subsubsection{O modelo empirico para a função de demanda por turismo}

Com a finalidade de obter as estimativas dos parâmetros associados com as variáveis acima descritas, bem como testar as hipóteses formuladas, foi especificado o seguinte modelo econométrico:

$$
Y_{j}=\sum_{i=1}^{6} \alpha_{i} Z_{i j}+\sum_{i=1}^{6} \beta_{i} X_{i j}+u_{j} \quad(j=1,2, \ldots, 355)
$$

em que:

$$
\begin{aligned}
& Y_{j}=\quad \text { número de dias que o turista } j \text { permaneceu no Ceará } \\
& Z_{1 j}=\left\{\begin{array}{l}
1 \text { se o turista } j \text { for do sexo masculino } \\
0 \text { se o turista } j \text { for do sexo feminino }
\end{array}\right. \\
& Z_{2 j}=\left\{\begin{array}{l}
1 \text { se a viagem do turista } j \text { foi organizada por uma agência } \\
\text { de viagens } \\
0 \text { caso contrário }
\end{array}\right. \\
& Z_{3 j}=\left\{\begin{array}{l}
1 \text { se o turista } j \text { for casado } \\
0 \text { caso contrário }
\end{array}\right. \\
& Z_{A j}=\left\{\begin{array}{l}
1 \text { se o turista } j \text { estava viajando sozinho } \\
0 \text { caso contrário }
\end{array}\right.
\end{aligned}
$$

As variáveis $Z_{5}$ e $Z_{6}$ referem-se ao motivo que levou o individuo a fazer a viagem para o Ceará. Assumiu-se que, quando o individuo viaja por motivo de trabalho, cursos, congressos e compras não há influência sobre a quantidade de dias que o mesmo irá permanecer no local do atrativo. Isso porque essas viagens, geralmente, são com dias determinados. 
$Z_{5 j}=\left\{\begin{array}{l}1 \text { se o motivo da viagem foi recreio/lazer } \\ 0 \text { para os demais motivos (com exceção do motivo visitas }\end{array}\right.$ a parentes/amigos)

$Z_{\sigma j}=\quad\{1$ se o motivo da viagem foi visitas a parentes/amigos

0 para os demais motivos (com exceção do motivo recreio/lazer)

A variável $X_{1}$ refere-se ao grau de escolaridade dos turistas.

$X_{l j}=\left\{\begin{array}{l}1 \text { se o turista } j \text { possui o primeiro grau } \\ 2 \text { se o turista } j \text { possui o segundo grau ou curso técnico } \\ 3 \text { se o turista } j \text { possui nivel superior }\end{array}\right.$

A variável $X_{2}$ refere-se à renda familiar mensal dos turistas.
1 se o turista $j$ possui renda de até $\mathrm{R} \$ 200,00$
2 se o turista $j$ possui renda de $R \$ 200,00$ a $R \$ 500,00$
$X_{2 j}=\quad 3$ se o turista $j$ possui renda de $\mathrm{R} \$ 500,00$ a $\mathrm{R} \$ 1000,00$
4 se o turista $j$ possui renda de $R \$ 1000,00$ a $R \$$ 3000,00

5 se o turista $j$ possui renda superior a $\mathrm{R} \$ 3000,00$
$X_{3 j}=\quad$ número de vezes que o turista $j$ veio ao Ceará nos últimos dois anos
$X_{4 j}=\quad$ idade do turista $j$, em anos
$X_{5 j}=\quad$ custos de transporte $(\mathrm{R} \$)$ incorrido pelo turista $j$
$X_{6 j}=\quad$ custos de viagem $(\mathrm{R} \$)$ incorrido pelo turista $j$
$u_{j}=\quad$ são erros aleatórios e que obedecem as pressuposições usuais

$\alpha_{i}$ e $\beta_{i} \quad$ são os parâmetros a serem estimados $(i=1,2, \ldots, 6)$ 


\subsubsection{A estimativa do valor de uso das praias}

A estimativa do valor de uso das praias do litoral cearense pode ser obtida através da integral definida da eq. (16), do ponto cujo custo de viagem é minimo, ou seja, o menor custo de viagem observado até o ponto cujo custo de viagem é máximo, isto é, o mais alto custo de viagem observado. Esta integração produz a seguinte função para o valor de uso:

$$
\begin{aligned}
& V_{\text {uso }}=\int_{X_{6}^{0}}^{X_{6}^{1}} Y d X_{6}=\sum_{i=1}^{6} \int_{X_{6}^{0}}^{X_{6}^{1}} a_{i} Z_{i} d X_{6}+\sum_{i=1}^{5} \int_{X_{6}^{0}}^{X_{6}^{1}} b_{i} X_{i} d X_{6}+\int_{X_{6}^{0}}^{X_{6}^{1}} b_{6} X_{6} d X_{6} \\
& V_{\text {uso }}=\left(X_{6}^{1}-X_{6}^{0}\right)\left[\left(\sum_{i=1}^{6} a_{i} Z_{i}\right)+\left(\sum_{i=1}^{5} b_{i} X_{i}\right)\right]+0,5 b_{6}\left[\left(X_{6}^{1}\right)^{2}-\left(X_{6}^{0}\right)^{2}\right]
\end{aligned}
$$

em que:

$$
\begin{aligned}
& X_{6}^{0}=\text { custo de viagem minimo; } \\
& X_{6}^{1}=\text { custo de viagem máximo; e, } \\
& a_{i} \text { e } b_{i} \text { são as estimativas dos parâmetros }(i=1,2, \ldots, 5)
\end{aligned}
$$

\subsection{Fonte dos dados}

Para elaboração deste estudo foram utilizados dados da Pesquisa de Demanda Turistica, bem como dados de outras fontes, tais como Guia Brasil Quatro Rodas (1996) e Guia Panrotas (1995). Outras informações foram também coletadas junto às empresas de ônibus que fazem linha para a cidade de Fortaleza.

A Pesquisa de Demanda Turistica realizada pela Secretaria do Turismo do Estado do Ceará foi feita junto aos turistas que visitaram as praias 
do litoral no mês de novembro de 1995. Este mês coincide com o periodo de baixa estação do turismo.

A pesquisa foi feita através de questionários aplicados aos turistas que já haviam passado um certo periodo de tempo na cidade de Fortaleza. De cada familia, apenas uma pessoa foi entrevistada. As entrevistas foram realizadas nos principais locais de saida dos turistas, ou seja, no aeroporto, na rodoviária, no porto e principais rodovias de acesso à cidade de Fortaleza. Dessa forma foi possivel obter informações de todos os tipos de visitantes, desde os que se hospedam nos hotéis classificados pela Empresa Brasileira de Turismo - EMBRATUR, até aqueles que ficam hospedados nas casas de parentes e/ou amigos.

O motivo da escolha da cidade de Fortaleza, para aplicação dos questionários, deve-se ao fato de que esta cidade funciona como centro turistico de distribuição para outras áreas litorâneas do Estado do Ceará, por ser dotada de uma melhor infra-estrutura turistica. Além disso, é um dos principais atrativos turisticos do Estado não só por suas praias, mas também porque fornece variadas opções de lazer noturno para os visitantes, bem como oportunidades de compras.

Os dados utilizados para estimar o tempo de viagem foram obtidos de duas fontes, a saber: Guia Brasil Quatro Rodas e Guia Panrotas. No Guia Brasil Quatro Rodas foram coletados dados a respeito das distâncias rodoviárias (em $\mathrm{km}$ ) entre Fortaleza e as outras capitais dos Estados de onde os turistas procedem. Já no Guia Panrotas foram coletados dados relativos ao tempo previsto de vôo.

Os dados de custo de transporte foram os fornecidos pelas empresas de ônibus que fazem linha para a cidade de Fortaleza (preços de passagens no periodo em que foi realizada a pesquisa), e os publicados no Guia Panrotas (preços de passagens aêreas). 


\section{RESULTADOS E DISCUSSÃO}

Neste capitulo são apresentados os principais resultados encontrados no trabalho. Essa apresentação é seguida, quando possivel, de uma breve discussão de alguns aspectos já mencionados nos capitulos anteriores. Ele é subdividido em duas partes. Na primeira parte, são apresentados os resultados que atendem ao primeiro objetivo, ou seja, fazer uma breve avaliação da demanda turistica. $\mathrm{Na}$ segunda parte, são apresentados os resultados referentes à avaliação econométrica.

\subsection{Avaliação da demanda turistica}

Neste sub-item são apresentados os resultados da estatística descritiva referente aos dados da amostra dos turistas que visitaram o Estado do Ceará e que foram entrevistados durante a realização da pesquisa. $O$ objetivo dessa apresentação é o de fazer algumas consideraçōes sobre o seu perfil.

Os questionários que geraram os dados utilizados nessa pesquisa foram aplicados e tabulados pela Secretaria do Turismo - SETUR, do Estado do Ceará. No total a amostra era constituida por 546 questionários. Após uma análise de identificação de variáveis, foram descartados 170 questionários por apresentarem algum tipo de problema como, por exemplo, renda declarada igual a zero, turistas que viajaram para fazer lazer e declararam que não tiveram gastos, e falta de informação sobre a procedência do turista. Assim sendo, restaram 376 observações. 


\subsubsection{Local de origem dos visitantes}

O número de turistas que se hospedaram nos hotéis classificados de Fortaleza durante o periodo em que foi realizada a pesquisa, foi igual a 19.733 (Ceará, 1995b). Destes, 7\% eram turistas estrangeiros e 93\% eram turistas nacionais ou domésticos ${ }^{20}$. No caso da amostra, das 376 observaçōes consideradas, $7,4 \%$ eram turistas estrangeiros e $92,6 \%$ eram turistas nacionais. Isso é uma indicação de que a amostra utilizada é uma boa representação da população de turistas.

No entanto, não foi possivel identificar quais os paises emissores de turistas para o Ceará. A identificação da origem só foi possivel para os Estados brasileiros, conforme pode ser observado na Tabela 2. Essa tabela mostra que não há uma grande diferença entre os Estados emissores, com exceção de São Paulo e Rio Grande do Norte. Estes dois Estados destacam-se em relação aos demais, apresentando uma percentagem dos turistas de 16,5\% e 13,5\%, respectivamente. A época em que foi realizada a pesquisa (mês de novembro, periodo de baixa estação, ou seja, è um periodo menos oneroso para quem viaja), pode ser considerada como um fator limitante para realização de viagens de longas distâncias. Isso porque dificulta a viagem de turistas que residem em regiões mais distantes dos atrativos, principalmente os que têm filhos em idade escolar, bem como os universitários e profissionais que trabalham na área de educação formal. Geralmente, as férias escolares são um fator critico para viagens mais longas.

\footnotetext{
${ }^{20}$ Não há dados disponíveis sobre o número de turistas que utilizaram outros meios de hospedagem (hotéis não classificados, pousadas, albergues, etc.). Estimativas feitas pela SETUR apontam um total de 12.118 turistas que se hospedaram nesses locais. No entanto, essas estimativas são agregadas, nāo havendo distinção entre os turistas nacionais e estrangeiros.
} 
Tabela 2. Principais Estados brasileiros emissores de turistas para o Estado do Ceará e percentagem de turistas nacionais e estrangeiros, nov./95.

\begin{tabular}{lcc}
\hline Discriminação & No de turistas & $\%$ \\
\hline Nacionais & 348 & 92,6 \\
São Paulo & 62 & 16,5 \\
Rio Grande do Norte & 51 & 13,5 \\
Distrito Federal & 32 & 8,5 \\
Rio de Janeiro & 28 & 7,4 \\
Pernambuco & 28 & 7,4 \\
Pará & 28 & 7,4 \\
Maranhão & 18 & 4,8 \\
Piaui & 16 & 4,3 \\
Bahia & 14 & 3,7 \\
Minas Gerais & 13 & 3,5 \\
Paraíba & 11 & 2,9 \\
Amazonas & 07 & 1,9 \\
Outros Estados & 40 & 10,8 \\
Estrangeiros & 28 & 7,4 \\
\hline TOTAL & 376 & 100,0 \\
\hline
\end{tabular}

Fonte: Ceará (1995a)

\subsubsection{Freqüêencia de visitação ao Ceará}

Analisando os dados disponiveis, constatou-se que cerca de $41,2 \%$ dos entrevistados estavam visitando o Estado pela primeira vez (ver Figura 2). Isso mostra que o turismo é uma atividade que precisa conquistar novos clientes, necessitando para isso de um planejamento, incluindo infraestrutura, organização de espaço, atrativos e qualidade ambiental. Assim, haverá estimulo para que os turistas potenciais decidam por viagens para o 
Ceará. Da mesma forma, eles poderão tornar-se agentes de divulgação do Estado nos seus respectivos locais de origem, desde que sejam bem recebidos.

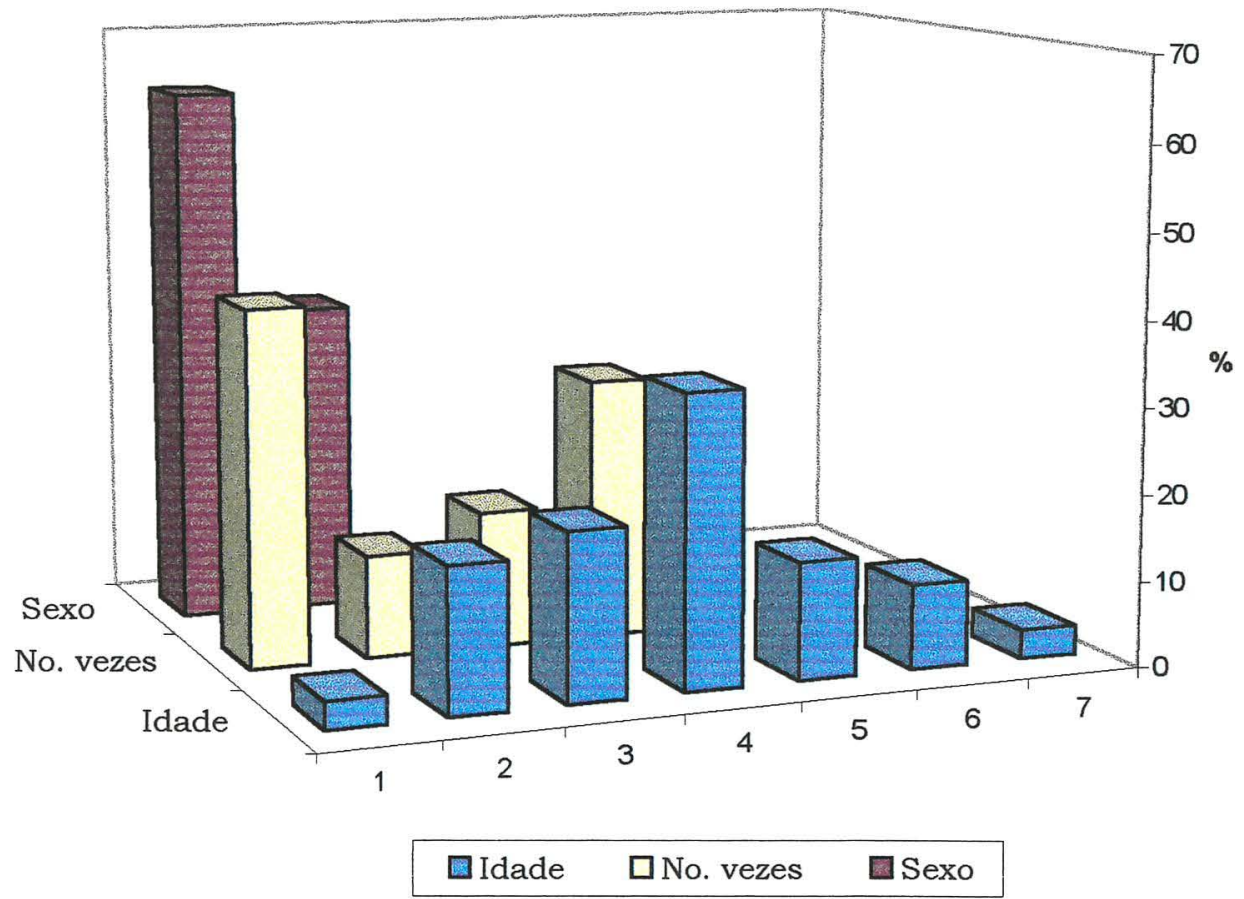

Fonte: Ceará (1995a)

Idade

1 - até 20 anos

2 - de 21 a 25 anos

3 - de 26 a 30 anos

4 - de 31 a 40 anos

5 - de 41 a 50 anos

6 - de 51 a 60 anos

7 - mais de 60 anos
№. de vezes

1 - uma vez

2 - duas vezes

3 - três vezes

4 - quatro vezes ou mais

\section{Sexo}

1 - masculino

2 - feminino

Figura 2 - Avaliação da demanda turística segundo a idade e o sexo dos visitantes e freqüência de visitação 


\subsubsection{Idade e sexo dos visitantes}

Observou-se uma grande diferença entre as faixas etárias dos visitantes (Figura 2). A faixa de 31 a 40 anos foi a que apresentou a maior percentagem, 33,8\%. A segunda maior percentagem, 19,4\%, coube à faixa entre 26 e 30 anos. Um número também significativo, 16,8\%, estava entre 21 e 25 anos e os demais entrevistados se distribuem nas outras classes.

Percebeu-se também um número muito baixo, $3,4 \%$, na faixa etária com mais de 60 anos. Essa constatação pode estar associada ao fato de que a maioria das pessoas pertencentes à categoria de aposentados no Brasil não possui condições financeiras favoráveis para realizar viagens de turismo ${ }^{21}$.

Com relação a pequena participação da faixa etária dos mais jovens (até 20 anos), 3,2\%, essa pode estar associada com a disponibilidade financeira para as despesas básicas como alimentação, passagens e hospedagem, bem como com a época em que foi feito o levantamento dos dados (mês de novembro), época em que os jovens pertencentes a essa faixa etária geralmente encontram-se ainda em atividades escolares, não podendo, assim, viajar para lugares mais distantes.

Analisando o sexo dos visitantes, determinou-se que 63,3\% eram do sexo masculino e $36,7 \%$ do sexo feminino. Bontempo (1994), fazendo uma avaliação sócio-econômica do turismo ecológico no Parque Nacional de Caparaó-MG, também encontrou valores semelhantes: 64\% dos respondentes do sexo masculino e $36 \%$ do sexo feminino. Esses dados podem estar relacionados com o fato de que as mulheres ainda têm menor liberdade para viajar sozinhas ou em grupos de excursão.

21 No Brasil, segundo informações do Anuärio Estatistico da Previdência Social (1994), a situação dos aposentados que residem na zona urbana é a seguinte: $63,23 \%$ recebem menos de 3 salários mínimos, 29,52\% recebem entre 3 e 6 salários minimos e apenas $7,21 \%$ recebem entre 7 e 10 salários minimos e apenas $0,04 \%$ recebem mais de 10 salários minimos. 


\subsubsection{Renda, tipo de transporte e meio de hospedagem utilizados pelos turistas}

A renda é uma variável cuja obtenção é bastante delicada, pois há uma certa relutância nas pessoas em fazer declarações a esse respeito. Nessa pesquisa, procurou-se avaliar o nivel de renda familiar mensal dos entrevistados. Constatou-se que $36,4 \%$ dos turistas entrevistados apresentavam renda mensal na classe de $\mathrm{R} \$ 1.000,00$ a $\mathrm{R} \$ 3.000,00$ e $22,6 \%$ com renda familiar mensal superior a $\mathrm{R} \$ 3.000,00$. Assim, praticamente $60 \%$ dos turistas entrevistados possuiam poder aquisitivo bem maior do que a grande parte da população brasileira (Tabela 3).

Tabela 3. Classes de renda mensal familiar dos turistas que visitaram o Estado do Ceará - novembro de 1995 e classes de renda das pessoas de 10 anos ou mais de idade, Brasil - 1995

\begin{tabular}{|c|c|c|c|c|c|}
\hline \multirow[t]{2}{*}{$\begin{array}{c}\text { Classe de renda } \\
\quad(\text { em } R \$)\end{array}$} & \multicolumn{2}{|c|}{ Turistas } & \multirow[t]{2}{*}{$\begin{array}{l}\text { Classe de renda } \\
\quad(e m R \$)\end{array}$} & \multicolumn{2}{|c|}{$\begin{array}{l}\text { População do } \\
\text { Brasil }^{*}\end{array}$} \\
\hline & № & $\%$ & & № & $\%$ \\
\hline até 200 & 16 & 4,3 & até 200 & 37.084 .216 & 30,9 \\
\hline de 200 a 500 & 62 & 16,5 & de 200 a 500 & 19.384 .481 & 16,2 \\
\hline de 500 a 1.000 & 76 & 20,2 & de 500 a 1.000 & 8.368 .040 & 6,9 \\
\hline de 1.000 a 3.000 & 137 & 36,4 & de 1.000 a 2.000 & 3.913 .334 & 3,3 \\
\hline \multirow[t]{2}{*}{ mais de 3.000} & 85 & 22,6 & mais de 2.000 & 2.067 .284 & 1,7 \\
\hline & & & Sem rendimentos & 49.163 .146 & 41,0 \\
\hline TOTAL & 376 & 100 & & 119.980 .502 & 100 \\
\hline
\end{tabular}

Fonte: Ceará (1995a)

*PNAD - 1995

Com relação ao tipo de transporte utilizado pelos turistas, quando estes utilizaram mais de um tipo, o presente estudo considerou o 
último tipo utilizado, ou seja, aquele em que o turista realmente chegou ao Ceará. Assim sendo, a grande maioria dos turistas entrevistados $(52,7 \%)$ utilizou o avião para se deslocar até Fortaleza. O segundo tipo de transporte mais utilizado foi o ônibus, com $39,1 \%$, considerando tanto o ônibus de linha regular como o ônibus fretado (Figura 3).

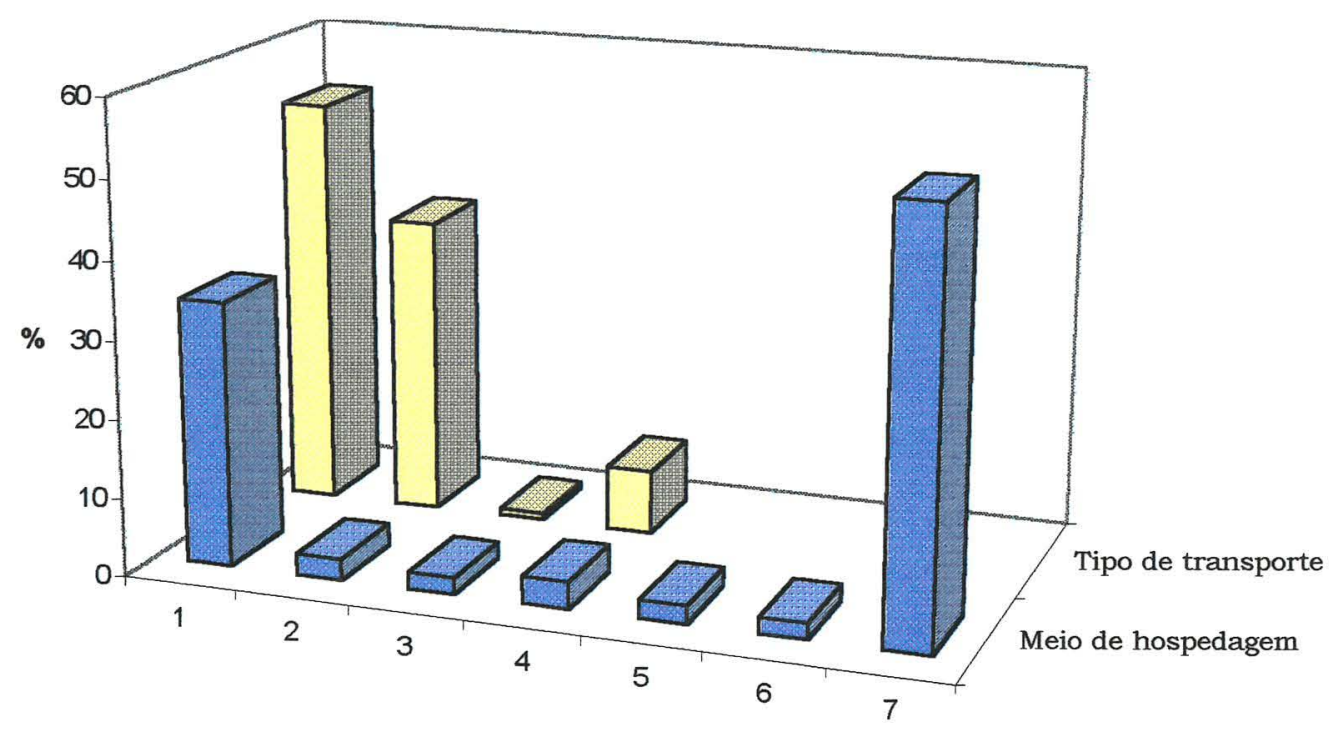

口 Meio de hospedagem $\square$ Tipo de transporte

Fonte: Ceará (1995a)

\section{Meio de Hospedagem}

1 - Hotel

5 - Apto. próprio

2 - Pousada

6 - Apto. temporada

3 - Albergue

7 - Casa de parentes/amigos

4 - Flat
Tipo de Transporte

1 - Avião

2 - Ônibus de linha

3 - Ônibus fretado

4 - Carro particular

Figura 3 - Avaliação da demanda turística segundo o meio de hospedagem e o tipo de transporte utilizados. 
No que diz respeito a hospedagem, analisando os dados obtidos, constatou-se que mais da metade dos turistas entrevistados, 53,5\%, hospedaram-se na casa de parentes e/ou amigos. Seguindo a análise, verificou-se que $33,8 \%$ dos turistas utilizaram hotéis. Os demais foram distribuidos quase na mesma percentagem para outras categorias de hospedagem, conforme pode ser observado na Figura 3.

\subsubsection{Nivel de escolaridade, estado civil, composição do grupo e motivo da viagem dos turistas}

Quanto ao nivel de escolaridade dos turistas, observa-se que $48,1 \%$ possuiam o curso superior. Acrescido àqueles com segundo grau $(39,4 \%)$, soma-se um total de $87,5 \%$ dos visitantes que tinham pelo menos o segundo grau (Tabela 4). Ou seja, os turistas que visitaram o Ceará no periodo analisado tinham nivel alto de escolaridade.

Tabela 4. Nivel de escolaridade dos turistas que visitaram o Ceará, nov./95

\begin{tabular}{lcc}
\hline Escolaridade & № & $\%$ \\
\hline 1o grau & 41 & 10,9 \\
2o grau & 148 & 39,4 \\
Técnico & 6 & 1,6 \\
Superior & 181 & 48,1 \\
\hline TOTAL & 376 & 100,0 \\
\hline
\end{tabular}

Fonte: Ceará (1995a)

Dessa forma, pode-se levantar a hipótese de que a inclusão de disciplinas relacionadas ao meio ambiente nos programas de ensino formal, poderá contribuir para a conservação do meio ambiente, em particular, das 
áreas costeiras. Visto que, segundo Hendee et al.22, citado por Bontempo (1994), quanto mais elevada for a formação dos individuos mais conscientes estes serão quanto à conservação dos recursos naturais.

Com relação ao estado civil dos turistas, praticamente não hả diferença entre a percentagem de casados e a soma da percentagem dos solteiros e separados, de 47,9\% e 50\%, respectivamente. Analisando a composição do grupo, verificou-se que a maioria dos turistas entrevistados viajou sozinha $(58,2 \%)$. Cruzando essas informações (Tabela 5), constatou-se que, dos turistas amostrados, $27,9 \%$ eram solteiros e viajavam sozinhos, e $24,5 \%$ eram os casados e, tambêm, viajavam desacompanhados. Utilizando o teste de hipótese para comparação de proporções, pôde-se verificar que, ao nivel de significância de $1 \%$, não houve diferença estatisticamente significativa entre os turistas solteiros e que viajavam sozinhos e os casados que também viajavam sozinhos.

Tabela 5. Estado civil por composição do grupo de viagem dos turistas que visitaram o Ceará, nov./95

\begin{tabular}{|c|c|c|c|c|c|c|c|c|}
\hline \multirow{3}{*}{$\begin{array}{l}\text { Estado } \\
\text { civil }\end{array}$} & \multicolumn{6}{|c|}{ Composiçāo do grupo } & & \\
\hline & \multicolumn{2}{|c|}{ Sozinho } & \multicolumn{2}{|c|}{$\begin{array}{c}\text { Com a } \\
\text { familia }\end{array}$} & \multicolumn{2}{|c|}{ Em grupo } & \multicolumn{2}{|c|}{ Total } \\
\hline & № & $(\%)$ & № & $(\%)$ & № & $(\%)$ & № & $(\%)$ \\
\hline Solteiro & 105 & 27,9 & 24 & 6,4 & 31 & 8,2 & 160 & 42,5 \\
\hline Casado & 92 & 24,5 & 68 & 18,1 & 20 & 5,3 & 180 & 47,9 \\
\hline Viúvo & 3 & 0,8 & 0 & 0 & 1 & 0,3 & 4 & 1,1 \\
\hline Separado & 17 & 4,5 & 6 & 1,6 & 5 & 1,3 & 28 & 7,5 \\
\hline Outros & 2 & 0,5 & 2 & 0,5 & 0 & 0 & 4 & 1,0 \\
\hline Total & 219 & 58,2 & 100 & 26,6 & 57 & 15,2 & 376 & 100 \\
\hline
\end{tabular}

Fonte: Ceará (1995a)

${ }^{22}$ HENDEE, J. C.; STANKEY, G. H.; LUCAS, R.C. Wilderness manegement. Forest, U.S. Departament of Agriculture. Miscellaneous Publication, 1978. 381p. 
Quanto ao motivo de viagem ao Estado do Ceará, os resultados da pesquisa mostram que a principal razão foi a procura de lazer e recreação (44\%). O segundo motivo foi o trabalho e/ou negócios (27\%) (Tabela 6). Assim, novamente, pode-se dizer que o mercado turistico no Estado do Cearä apresenta um grande potencial para se consolidar como uma das bases da economia, pois tem-se turistas com elevado nivel de renda e com disposição para gastar com recreação e lazer.

Tabela 6. Principal motivo da viagem por composição do grupo de viagem dos turistas que visitaram o Ceará, nov./95

\begin{tabular}{|c|c|c|c|c|c|c|c|c|}
\hline \multirow{3}{*}{$\begin{array}{c}\text { Motivo } \\
\text { da Viagem }\end{array}$} & \multicolumn{6}{|c|}{ Composição do grupo } & & \\
\hline & \multicolumn{2}{|c|}{ Sozinho } & \multicolumn{2}{|c|}{ Com a familia } & \multicolumn{2}{|c|}{ Em grupo } & \multicolumn{2}{|c|}{ Total } \\
\hline & № & $(\%)$ & № & $(\%)$ & № & $(\%)$ & № & $(\%)$ \\
\hline Lazer & 79 & 21,01 & 52 & 13,83 & 34 & 9,04 & 165 & 43,88 \\
\hline Trabalho & 70 & 18,62 & 20 & 5,32 & 11 & 2,93 & 101 & 26,86 \\
\hline $\begin{array}{l}\text { Congressos } \\
\text { /Cursos }\end{array}$ & 14 & 3,72 & 6 & 1,60 & 7 & 1,86 & 27 & 6,78 \\
\hline $\begin{array}{l}\text { Visita a } \\
\text { parentes }\end{array}$ & 43 & 11,44 & 16 & 4,26 & 3 & 0,80 & 62 & 16,49 \\
\hline Compras & 9 & 2,39 & 3 & 0,80 & 0 & 0 & 12 & 3,19 \\
\hline Saüde & 3 & 0,80 & 3 & 0,80 & 0 & 0 & 6 & 1,60 \\
\hline Outros & 1 & 0,27 & 0 & 0 & 2 & 0,53 & 3 & 0,80 \\
\hline Total & 219 & 58,24 & 100 & 26,60 & 57 & 15,16 & 376 & 100 \\
\hline
\end{tabular}

Fonte: Ceará (1995a)

Cruzando as informações com relação ao motivo da viagem para o Ceará com a composição do grupo de viagem, verificou-se que dos turistas que vieram a procura de lazer/recreação, 47,88\% estavam viajando sozinhos, $31,52 \%$ viajavam com a familia e $20,61 \%$ viajavam em grupo. Isso mostra que há necessidade de incentivar as atividades culturais, principalmente no 
periodo noturno, a fim de que essas pessoas possam se ambientar com maior facilidade.

\subsection{Estimativa da função de demanda por turismo no litoral cearense}

É importante ressaltar, novamente, que a literatura não deixa claro qual a forma funcional que deve ser utilizada em estudos de demanda por recreação e nem as variáveis exógenas que devem ser usadas para explicar o problema a ser estudado, com exceção dos custos de viagem. Vários autores têm discutido esse assunto, dentre eles Ziemer et al. (1980), Strong (1983), Adamowicz et al. (1989) e Willins \& Garrod (1991).

Como não existe uma definição da forma funcional correta, optou-se por fazer quatro modelos econométricos diferentes e, em seguida, escolher para as análises pertinentes aquele que apresentasse melhores resultados estatisticos. Assim, foram usadas as seguintes formas funcionais: forma linear, forma logaritmica na variâvel dependente, forma logaritmica nas variáveis exógenas e enđógena e forma logaritmica nas variáveis independentes.

No entanto, no presente estudo, a maior parte das variáveis é qualitativa e assumiu valor zero ou um. Dessa forma, não foi possivel aplicar uma transformação logaritmica direta nessas variáveis. Assim, para que fosse possivel obter um modelo com transformaçāo logaritmica em ambas as variáveis e um com transformação logaritmica nas variáveis independentes, assumiu-se que esses valores $\left(\begin{array}{lll}0 & \mathrm{e} & 1\end{array}\right)$ já eram os resultados dessa transformação. Ou seja, assumiu-se que o logaritmo das variáveis $Z_{1}$ a $Z_{6}$ era igual a 0 ou 1, dependendo da situação.

Os referidos modelos de equações de demanda foram estimados utilizando-se o método dos mínimos quadrados ordinários, fazendo uso do 
programa estatístico SAS. Os resultados referentes às estimativas dos parâmetros, para os quatro modelos econometricos, bem como os testes estatisticos, estão especificados nas Tabelas 7, 8, 9 e 10.

Tabela 7. Estimativa dos parâmetros da função de demanda por turismo, Estado do Ceará, nov./95, forma linear.

\begin{tabular}{lcc}
\hline \multicolumn{1}{c}{ Variáveis explicativas } & $\begin{array}{c}\text { Coeficientes de } \\
\text { regressão }\end{array}$ & $\begin{array}{c}\text { Teste " } \mathrm{t} \text { " de } \\
\text { Student }\end{array}$ \\
\hline Constante & $21,2669 *$ & 6,081 \\
Sexo $\left(\mathrm{Z}_{1}\right)$ & $0,6813 \mathrm{Ns}$ & 0,504 \\
Organização da viagem $\left(\mathrm{Z}_{2}\right)$ & $-3,8073 * *$ & $-2,088$ \\
Estado civil $\left(\mathrm{Z}_{3}\right)$ & $-0,6921 \mathrm{Ns}$ & $-0,518$ \\
Composição do grupo de viagem $\left(\mathrm{Z}_{4}\right)$ & $-1,9915 \mathrm{Ns}$ & $-1,529$ \\
Motivo da viagem - recreio/lazer $\left(\mathrm{Z}_{5}\right)$ & $2,5792 * * *$ & 1,844 \\
Motivo da viagem - visitas a parentes $\left(\mathrm{Z}_{6}\right)$ & $5,8777 *$ & 3,154 \\
Grau de escolaridade $\left(\mathrm{X}_{1}\right)$ & $-1,1550 \mathrm{Ns}$ & $-1,058$ \\
Nível de renda $\left(\mathrm{X}_{2}\right)$ & $-1,4767 * *$ & $-2,106$ \\
Número de visitas ao Ceará $\left(\mathrm{X}_{3}\right)$ & $-0,4052 \mathrm{Ns}$ & $-0,843$ \\
Idade $\left(\mathrm{X}_{4}\right)$ & $-0,0048 \mathrm{Ns}$ & $-0,086$ \\
Custos de transporte $\left(\mathrm{X}_{5}\right)$ & $0,0069 * *$ & 2,033 \\
Custos de viagem $\left(\mathrm{X}_{6}\right)$ & $-0,0131 *$ & $-4,575$ \\
& & \\
Coeficiente de determinação $\left(\mathrm{R}^{2}\right)$ & 0,1845 & \\
Valor da estatistica $\mathrm{F}(12 ; 342)$ & $6,450 *$ & \\
\hline
\end{tabular}

Fonte: Resultados da pesquisa

Nivel de significância: * significativo a $1 \%$

** significativo a $5 \%$

*** significativo a $10 \%$

Ns não significativo 
Tabela 8. Estimativa dos parâmetros da função de demanda por turismo, Estado do Ceará, nov./95, forma semi-log na variâvel dependente.

\begin{tabular}{lcc}
\hline \multicolumn{1}{c}{ Variáveis explicativas } & $\begin{array}{c}\text { Coeficientes de } \\
\text { regressão }\end{array}$ & $\begin{array}{c}\text { Teste “t” de } \\
\text { Student }\end{array}$ \\
\hline Constante & $2,9050 *$ & 11,446 \\
Sexo $\left(Z_{1}\right)$ & $-0,0114 \mathrm{Ns}$ & $-0,117$ \\
Organização da viagem $\left(Z_{2}\right)$ & $-0,2758 * *$ & $-2,084$ \\
Estado civil $\left(Z_{3}\right)$ & $-0,0808 \mathrm{Ns}$ & $-0,834$ \\
Composição do grupo de viagem $\left(Z_{4}\right)$ & $-0,1577 * * *$ & $-1,670$ \\
Motivo da viagem - recreio/lazer $\left(Z_{5}\right)$ & $0,3996 *$ & 3,939 \\
Motivo da viagem - visitas a parentes $\left(Z_{6}\right)$ & $0,5526 *$ & 4,086 \\
Grau de escolaridade $\left(\mathrm{X}_{1}\right)$ & $-0,0397 \mathrm{Ns}$ & $-0,502$ \\
Nível de renda $\left(\mathrm{X}_{2}\right)$ & $-0,1353 * *$ & $-2,660$ \\
Número de visitas ao Ceará $\left(\mathrm{X}_{3}\right)$ & $-0,0299 \mathrm{Ns}$ & $-0,857$ \\
Idade $\left(\mathrm{X}_{4}\right)$ & $-0,0049 \mathrm{Ns}$ & $-1,206$ \\
Custos de transporte $\left(\mathrm{X}_{5}\right)$ & $0,0004 * *$ & 1,671 \\
Custos de viagem $\left(\mathrm{X}_{6}\right)$ & $-0,0013 *$ & $-6,310$ \\
Coeficiente de determinação $\left(\mathrm{R}^{2}\right)$ & & \\
Valor da estatistica $\mathrm{F}(12 ; 342)$ & 0,3008 & \\
\hline
\end{tabular}

Fonte: Resultados da pesquisa

Nivel de significância: * significativo a $1 \%$

** significativo a $5 \%$

*** significativo a $10 \%$

Ns não significativo 
Tabela 9. Estimativa dos parâmetros da função de demanda por turismo, Estado do Ceará, nov./95, forma log-log.

\begin{tabular}{lcc}
\hline \multicolumn{1}{c}{ Variáveis explicativas } & $\begin{array}{c}\text { Coeficientes de } \\
\text { regressão }\end{array}$ & $\begin{array}{c}\text { Teste “t” de } \\
\text { Student }\end{array}$ \\
\hline Constante & $4,7740 *$ & 8,863 \\
Sexo $\left(\mathrm{Z}_{1}\right)$ & $-0,0187 \mathrm{Ns}$ & $-0,208$ \\
Organização da viagem $\left(\mathrm{Z}_{2}\right)$ & $-0,2485 * *$ & $-2,046$ \\
Estado civil $\left(\mathrm{Z}_{3}\right)$ & $-0,1262 \mathrm{Ns}$ & $-1,395$ \\
Composição do grupo de viagem $\left(\mathrm{Z}_{4}\right)$ & $-0,0857 \mathrm{Ns}$ & $-0,986$ \\
Motivo da viagem - recreio/lazer $\left(\mathrm{Z}_{5}\right)$ & $0,3282 *$ & 3,535 \\
Motivo da viagem - visitas a parentes $\left(\mathrm{Z}_{6}\right)$ & $0,5288 *$ & 4,275 \\
Grau de escolaridade $\left(\mathrm{X}_{1}\right)$ & $-0,2278 \mathrm{Ns}$ & $-1,609$ \\
Nivel de renda $\left(\mathrm{X}_{2}\right)$ & $0,0529 \mathrm{Ns}$ & 0,365 \\
Número de visitas ao Ceará $\left(\mathrm{X}_{3}\right)$ & $-0,0539 \mathrm{Ns}$ & $-0,789$ \\
Idade $\left(\mathrm{X}_{4}\right)$ & $-0,1988 \mathrm{Ns}$ & $-1,365$ \\
Custos de transporte $\left(\mathrm{X}_{5}\right)$ & $0,0620 * * *$ & 1,722 \\
Custos de viagem $\left(\mathrm{X}_{6}\right)$ & $-0,4843 *$ & $-10,467$ \\
Coeficiente de determinação $\left(\mathrm{R}^{2}\right)$ & & \\
Valor da estatística $\mathrm{F}(12 ; 342)$ & 0,4130 & \\
\hline
\end{tabular}

Fonte: Resultados da pesquisa

Nivel de significância: * significativo a $1 \%$

** significativo a $5 \%$

*** significativo a $10 \%$

NS não significativo 
Tabela 10. Estimativa dos parâmetros da função de demanda por turismo, Estado do Ceará, nov./95, forma semi-log nas variáveis independentes.

\begin{tabular}{lcc}
\hline \multicolumn{1}{c}{ Variáveis explicativas } & $\begin{array}{c}\text { Coeficientes de } \\
\text { regressão }\end{array}$ & $\begin{array}{c}\text { Teste "t" de } \\
\text { Student }\end{array}$ \\
\hline Constante & $39,5078 *$ & 5,324 \\
Sexo $\left(Z_{1}\right)$ & 0,7357 Ns & 0,593 \\
Organização da viagem $\left(Z_{2}\right)$ & $-3,2125 * * *$ & $-1,920$ \\
Estado civil $\left(Z_{3}\right)$ & $-1,2748$ Ns & $-1,023$ \\
Composição do grupo de viagem $\left(Z_{4}\right)$ & $-1,0511$ Ns & $-0,878$ \\
Motivo da viagem - recreio/lazer $\left(Z_{5}\right)$ & 1,3616 ss & 1,064 \\
Motivo da viagem - visitas a parentes $\left(Z_{6}\right)$ & $5,5067 * *$ & 3,231 \\
Grau de escolaridade $\left(X_{1}\right)$ & $-4,5650 * *$ & $-2,340$ \\
Nivel de renda $\left(X_{2}\right)$ & 1,5074 Ns & 0,754 \\
Número de visitas ao Ceará $\left(X_{3}\right)$ & $-0,8529$ Ns & 0,905 \\
Idade $\left(X_{4}\right)$ & $-0,6654$ Ns & $-0,332$ \\
Custos de transporte $\left(X_{5}\right)$ & $0,9384 * * *$ & 1,890 \\
Custos de viagem $\left(X_{6}\right)$ & $-5,9429 *$ & $-9,322$ \\
Coeficiente de determinação $\left(R^{2}\right)$ & & \\
Valor da estatística $F(12 ; 342)$ & 0,3158 & \\
\hline
\end{tabular}

Fonte: Resultados da pesquisa

Nivel de significância: * significativo a $1 \%$

** significativo a $5 \%$

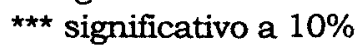

NS não significativo 
Analisando os resultados, verificou-se que um grande nümero de variáveis explicativas nāo foi significativa. Percebeu-se também que os valores do coeficiente de determinação $\left(R^{2}\right)$ encontrados em todos os modelos foram baixos. No entanto, em se tratando de dados cross-section era de se esperar que isso acontecesse, haja vista a grande variação que existe em dados dessa natureza.

A comparação de modelos com variáveis dependentes distintas, por exemplo, entre um modelo sem transformação logaritmica nas variâveis e um outro com transformação logaritmica na variável dependente, não pode ser feita pelos $R^{2}$. Porém, pode ser feita através do nivel de significância dos parâmetros, ou seja, através do teste " $\mathrm{t}$ " de Student. Dessa forma, de posse de alguns modelos econométricos, é escolhido aquele que apresentar um maior número de variáveis significativas, a um dado nivel de significância.

Com relação a multicolinearidade elevada, Judge et al. (1988) sugerem que ela está presente nos casos em que a variance inflation factores $(V I F)^{23}$ è maior ou igual a 5 . Assim, considerando-se os baixos valores para a VIF (ver Tabela 11), pode-se ignorar sua presença nos quatro modelos testados.

Dessa forma, tomando-se por base todas as informações anteriormente descritas, procedeu-se a escolha da forma funcional que apresentou o melhor ajuste. Neste estudo o modelo semi-log na variável dependente foi o escolhido. Além disso, está de acordo com estudos anteriores

23 A variance inflation factors para uma variável independente $X_{i}$ pode ser calculada pela seguinte fórmula:

$$
V I F_{i}=\frac{1}{1-R_{i}^{2}}
$$

em que: $R_{i}^{2}$ é o coeficiente de determinação que é obtido quando é feita uma regressão da variável $X_{i}$ contra todas as outras variáveis independentes (Judge et al., 1988). 
Tabela 11. Estimativas dos variance inflation factors para as formas funcionais: linear, semi-log na variável dependente, log-log e semi-log nas variáveis independentes

\begin{tabular}{c|cc|c|c}
\hline \multirow{2}{*}{ Variáveis } & \multicolumn{4}{|c}{ Variance Inflation Factors } \\
\cline { 2 - 5 } & Modelo 1 & Modelo 2 & Modelo3 & Modelo 4 \\
\hline$Z_{1}$ & 1,218 & 1,218 & 1,221 & 1,221 \\
$Z_{2}$ & 1,197 & 1,197 & 1,200 & 1,200 \\
$Z_{3}$ & 1,284 & 1,284 & 1,331 & 1,331 \\
$Z_{4}$ & 1,177 & 1,177 & 1,187 & 1,187 \\
$Z_{5}$ & 1,381 & 1,381 & 1,377 & 1,377 \\
$Z_{6}$ & 1,347 & 1,347 & 1,343 & 1,343 \\
$X_{1}$ & 1,523 & 1,523 & 1,492 & 1,492 \\
$X_{2}$ & 1,745 & 1,745 & 1,943 & 1,943 \\
$X_{3}$ & 1,100 & 1,100 & 1,122 & 1,122 \\
$X_{4}$ & 1,279 & 1,279 & 1,370 & 1,370 \\
$X_{5}$ & 1,210 & 1,210 & 1,426 & 1,426 \\
$X_{6}$ & 1,118 & 1,118 & 1,282 & 1,282 \\
\hline
\end{tabular}

Fonte: Resultados da pesquisa

Modelo 1 - forma linear

Modelo 2 - forma semi-log na variável dependente

Modelo 3 - forma log-log

Modelo 4 - forma semi-log nas variáveis independentes 
sobre estimativas de função de demanda por recreação e de beneficios recreacionais, tais como: Gibbs (1974), McConnell (1977) e Navrud \& Mungatana (1994).

Assim, a função demanda por turismo no litoral do Estado do Ceará foi expressa por:

$$
\begin{aligned}
\ln Y= & 2,9050-0,0114 Z_{1}-0,2758 Z_{2}-0,0808 Z_{3}-0,1577 Z_{4}+ \\
& +0,3996 Z_{5}+0,5526 Z_{6}-0,0397 X_{1}-0,1353 X_{2}-0,0299 X_{3}- \\
& -0,0049 X_{4}+0,0004 X_{5}-0,0013 X_{6}
\end{aligned}
$$

Analisando o comportamento das variáveis explicativas no modelo de regressão adotado verificou-se que as variâveis sexo, estado civil e grau de escolaridade não têm influência significativa sobre a permanência dos turistas. Alêm disso, o sinal da variável grau de escolaridade não está de acordo com a literatura econômica. Este fato pode estar associado com a dificuldade que se tem em mensurar uma variável que identifique o nivel educacional de uma população. No presente caso só foi possível identificar o nivel de escolaridade do turista atribuindo-se ao mesmo um valor, de 1 a 3 , dependendo do respectivo nivel.

A variável organização da viagem $\left(Z_{2}\right)$ foi significativa e com o sinal de acordo com o esperado. Isto é, estatisticamente, ao nivel de $5 \%$ de significāncia, quando a viagem é organizada por uma agência de viagens, o turista permanece menos dias em Fortaleza. Uma provável explicação para isso é que quando o turista viaja por uma agência é com pacotes que tem os dias de permanência pré-determinados, geralmente não tendo a oportunidade de prorrogar a sua permanência no local, ou quando tem, os custos para isso são relativamente mais elevados.

As variáveis motivo da viagem - lazer/recreio $\left(Z_{5}\right)$ e motivo da viagem - visitas a parentes $\left(Z_{\sigma}\right)$ são também significativas e com os sinais de 
acordo com as hipóteses anteriormente levantadas. Ou seja, considerando um nivel de significância de $1 \%$, pode-se inferir que, se o motivo da viagem do turista for um dos dois acima descritos, ele permanecerá mais tempo em Fortaleza. Isso quando comparado com os motivos trabalho, congressos, compras etc.

A variável composição do grupo de viagem (se o turista viajou sozinho ou com familiares e/ou em grupo - $Z_{4}$ ) é estatisticamente significativa e o sinal do coeficiente de acordo com o esperado. Ou seja, quem viaja sozinho tende a permanecer menos no local. Isto, provavelmente, pode estar associado ao fato de que o turista que viaja sozinho sentir-se um pouco "sem ambiente".

A variável renda $\left(\mathrm{X}_{2}\right)$ foi significativa, mas o sinal do coeficiente de regressão a ela associado não está de acordo com o que reza a teoria econômica, ou seja, que, quanto maior a renda dos turistas, maior será o montante de produtos turisticos demandado. Uma explicação para esse fato, sinal negativo para o coeficiente da variável renda, pode estar associado com o fato de que os turistas que possuem um nivel de renda mais elevado permanecem poucos dias num mesmo local de recreação. Assim, aumentandose o nivel de renda do turista, ele tenderá a ficar menos dias em Fortaleza, mas irá visitar outras cidades turísticas da região Nordeste.

A variável número de visitas ao Ceará $\left(\mathrm{X}_{3}\right)$, apesar de não ter influência significativa sobre a permanência dos turistas, apresentou sinal negativo do coeficiente, de acordo com o esperado, ou seja, esperava-se que, à medida que aumentasse a freqüência de visitas, a permanência média diminuisse.

A variável idade dos turistas não se mostrou significativa, mas apresentou o sinal negativo do coeficiente de acordo com o esperado, ou seja, esperava-se que a medida que aumentasse a idade, diminuisse a permanência média no Ceará, visto que se acredita que pessoas com mais idade costumam viajar para locais mais próximos do seu local de origem. Mesmo não sendo 
significativa, optou-se por deixá-la no modelo, visto que é considerada por muitos autores como uma das variáveis sócio-econômicas mais importante nos estudos de demanda por recreação (Navrud \& Mungatana, 1994).

No que diz respeito às variáveis custos de transporte $\left(\mathrm{X}_{5}\right)$ e custos de viagem $\left(\mathrm{X}_{6}\right)$, os resultados foram os que seguem. Para o custo de transporte esperava-se que uma vez que o individuo está de férias e decidiu fazer a viagem, caso ocorresse um aumento desse custo ele procuraria permanecer mais tempo no local da recreação, para compensar o investimento feito. Essa hipótese não foi rejeitada, tanto pelo sinal positivo dessa variável, bem como pela sua significância.

Considerando a variável custos de transporte $\left(X_{5}\right)$ pode-se inferir que um $1 \%$ nos custos de transporte irá ocasionar um aumento de $0,09 \%$, no ponto médio, na permanência dos turistas no Ceará, ou seja, um aumento nos custos de transporte irá resultar num aumento proporcionalmente menor na permanência média dos turista nos Ceará.

Os resultados com relação a variável custos de viagem $\left(\mathrm{X}_{6}\right)$ foram os esperados, ou seja, esperava-se que a mesma apresentasse uma relação negativa com a quantidade demandada de recreação. Essa relação pode ser verificada pelo sinal do coeficiente correspondente, bem como pela significância do mesmo.

Considerando os custos de viagem $\left(\mathrm{X}_{6}\right)$ como sendo proxy do preço pago pelos turistas para utilizarem as praias, no ponto médio, a elasticidade preço da demanda por turismo é igual a $-0,22$. Portanto, a demanda por turismo pode ser classificada como inelástica. Isso significa que um aumento dos custos de viagem resultará numa redução proporcionalmente menor na permanência média dos turistas no Estado do Ceará, mantidas constantes as demais variáveis.

Essa estimativa do coeficiente de elasticidade preço da demanda está de acordo com estudos anteriores de recreaçāo. Segundo Navrud \& 
Mungatana (1994) a elasticidade preço da demanda por recreaçāo é baixa quando a percentagem da renda gasta com a atividade também é baixa. Isso ocorre, também, para atividades recreacionais que são especializadas e de alta qualidade. A atividade turistica no Estado do Ceará enquadra-se bem nessa descriçāo.

\subsection{Estimativa do valor recreacional das praias cearenses}

Como o modelo econométrico escolhido para proceder as análises pertinentes apresentou variáveis não significativas $\left(Z_{1}, Z_{3}, X_{1}, X_{3}\right.$ e $\left.X_{4}\right)$, foram reestimados novos modelos desconsiderando algumas dessas variáveis, mas sempre adotando a forma funcional semi-log na variável dependente. $O$ modelo estimado foi utilizado para fazer a estimativa do valor recreacional das praias do litoral cearense. O melhor resultado encontrado é apresentado a seguir (eq. 19):

$$
\begin{aligned}
& \ln Y=2,7929^{\star}-0,2742^{\star *} Z_{2}-0,1596^{* * *} Z_{4}+0,4208^{\star} Z_{5}+0,5748^{*} Z_{6}- \\
& \begin{array}{lllll}
(19,922) & (-2,120) \quad(-1,742) & (4,227) & (4,379)
\end{array} \\
& -0,1527^{\star} X_{2}-0,0064^{\star \star *} X_{4}+0,0004^{\star * *} X_{5}-0,0013^{*} X_{6} \\
& (-3,474) \quad(-1,660) \quad(1,696) \quad(-6,313) \\
& R^{2}=0,2973 \quad F_{(8 ; 346)}=18,298^{*}
\end{aligned}
$$

Os valores abaixo das estimativas dos parâmetros e entre parênteses referemse aos valores da estatistica " $t$ ”. Os coeficientes de regressão e o intercepto estatisticamente diferentes de zero ao nivel de significância de $1 \%, 5 \%$ e $10 \%$ são representados por * ${ }^{\star *} e^{* \star *}$, respectivamente. 
Para estimar o excedente do consumidor (que é utilizado como uma estimativa do valor de uso ou valor recreacional de um recurso ambiental), a literatura recomenda que todas as variáveis, com exceção dos custos de viagem, sejam substituidas pelos seus valores médios na equação de demanda pelo recurso ambiental.

Dessa forma, no presente trabalho, as variáveis $\mathrm{X}_{2}, \mathrm{X}_{4}$ e $\mathrm{X}_{5}$ foram substituidas pelos seus respectivos valores médios na equação de demanda apresentada na eq. 19. Essas substituições produziram a seguinte função:

$$
\ln Y=2,1042-0,2742 Z_{2}-0,1596 Z_{4}+0,4208 Z_{5}+0,5748 Z_{6}-0,0013 X_{6}
$$

Considerando as quatro variáveis qualitativas do modelo (eq.20), foram descritas dezesseis situações diferentes para a demanda, levando-se em conta a ocorrência ou não dessas variáveis, simultaneamente. No entanto, ao proceder a análise dos dados, verificou-se que os turistas amostrados não se distribuiam entre as dezesseis categorias identificadas. Ou seja, a freqüência de turistas nessas categorias variou de 0 a 83 . Assim, foram eliminadas as categorias que apresentaram freqüência igual a 0 , restando, dessa maneira, dez categorias. Cada uma das categorias obtidas, bem como suas respectivas equações são mostradas a seguir:

Categoria 1: se a viagem foi organizada por uma agência de viagens, se o turista viajava sozinho, se o motivo da viagem foi recreio/lazer ou outro motivo que não visitas a parentes/amigos. Para essa categoria a equação estimada foi:

$$
\ln Y=2,0912-0,0013 X_{6}
$$

Categoria 2: se a viagem foi organizada por uma agência de viagens, se o turista viajava sozinho, se o motivo da viagem foi outro que não recreio/lazer ou visitas a parentes/amigos. Para essa categoria a equação estimada foi: 


$$
\ln Y=1,6704-0,0013 X_{6}
$$

Categoria 3: se a viagem não foi organizada por uma agência de viagens, se o turista viajava sozinho, se o motivo da viagem foi visitas a parentes/amigos ou outro motivo que não recreio/lazer. Para essa categoria a equação estimada foi:

$$
\ln Y=2,5194-0,0013 X_{6}
$$

Categoria 4: se a viagem foi organizada por uma agência de viagens, se o turista viajava em grupo/familia, se o motivo da viagem foi recreio/lazer ou outro motivo que não visitas a parentes/amigos. Para essa categoria a equação estimada foi:

$$
\ln Y=2,5208-0,0013 X_{6}
$$

Categoria 5: se a viagem foi organizada por uma agência de viagens, se o turista viajava em grupo/familia, se o motivo da viagem foi outro que não recreio/lazer ou visitas a parentes/amigos. Para essa categoria a equação estimada foi:

$$
\ln Y=1,8300-0,0013 X_{6}
$$

Categoria 6: se a viagem não foi organizada por uma agência de viagens, se o turista viajava sozinho, se o motivo da viagem foi recreio/lazer ou outro motivo que não visitas a parentes/amigos. Para essa categoria a equação estimada foi:

$$
\ln Y=2,3654-0,0013 X_{6}
$$

Categoria 7: se a viagem não foi organizada por uma agência de viagens, se o turista viajava sozinho, se o motivo da viagem foi outro que nāo recreio/lazer ou visitas a parentes/amigos. Para essa categoria a equação estimada foi:

$$
\ln Y=1,9446-0,0013 X_{6}
$$


Categoria 8: se a viagem não foi organizada por uma agência de viagens, se o turista viajava em grupo/familia, se o motivo da viagem foi recreio/lazer ou outro motivo que não visitas a parentes/amigos. Para essa categoria a equação estimada foi:

$$
\ln Y=2,5250-0,0013 X_{6}
$$

Categoria 9: se a viagem não foi organizada por uma agência de viagens, se o turista viajava em grupo/familia, se o motivo da viagem foi visitas a parentes/amigos ou outro motivo que não recreio/lazer. Para essa categoria a equação estimada foi:

$$
\ln \mathrm{Y}=2,6790-0,0013 \mathrm{X}_{6}
$$

Categoria 10: se a viagem não foi organizada por uma agência de viagens, se o turista viajava em grupo/familia, se o motivo da viagem foi outro que não recreio/lazer ou visitas a parentes/amigos. Para essa categoria a equação estimada foi:

$$
\ln Y=2,1042-0,0013 X_{6}
$$

Integrando cada uma das funções de demanda por turismo, relacionadas com as categorias acima descritas (eq. 21 a 30), do ponto cujo custo de viagem foi minimo até o ponto cujo custo de viagem assumiu valor máximo, têm-se o valor de uso das praias do litoral cearense para cada uma das categorias. Esses resultados, bem como os custos de viagem minimo e máximo das categorias são mostrados na Tabela 12 . 
Tabela 12. Estimativa do valor recreacional das praias do litoral cearense e custos de viagem minimo e máximos em cada uma das categorias

\begin{tabular}{cccc}
\hline Categoria & $\begin{array}{c}\text { Custo de viagem } \\
\text { minimo (em R\$) }\end{array}$ & $\begin{array}{c}\text { Custo de viagem } \\
\text { máximo (em R\$) }\end{array}$ & $\begin{array}{c}\text { Valor de Uso } \\
\text { (em R\$) }\end{array}$ \\
\hline 1 & 45,25 & 263,33 & $1.449,11$ \\
2 & 50,91 & $2.306,00$ & $3.620,03$ \\
3 & 13,02 & 835,12 & $6.166,06$ \\
4 & 19,99 & 363,83 & $2.564,84$ \\
5 & 79,22 & 799,17 & $2.628,43$ \\
6 & 13,79 & 562,70 & $4.103,22$ \\
7 & 11,67 & $1.076,78$ & $3.968,81$ \\
8 & 8,85 & 505,00 & $4.514,08$ \\
9 & 8,23 & 290,38 & $3.404,39$ \\
10 & 8,23 & $2.005,00$ & $5.772,45$ \\
\hline
\end{tabular}

Fonte: Resultados da pesquisa

Conforme foi mencionado anteriormente, cada uma das categorias identificadas apresenta uma freqüência de turistas diferenciada. Dessa forma, ao invés de trabalhar com o valor de uso simples, achou-se melhor trabalhar com o valor de uso ponderado para cada uma das dez categorias especificadas. A referida ponderação foi feita pelo número de turistas pertencentes a cada uma das categorias. Isto $\dot{e}$, o valor de uso estimado pelo método da integração para cada uma das categorias foi ponderado (multiplicado) pelas suas respectivas freqüências. Esses resultados são mostrados na Tabela 13. 
Tabela 13. Estimativa do valor recreacional das praias do litoral cearense, número de turistas e valor de uso ponderado em cada uma das categorias

\begin{tabular}{cccr}
\hline Categoria & $\begin{array}{c}\text { Valor de uso } \\
(\mathrm{em} \mathrm{R} \$) \\
(1)\end{array}$ & $\begin{array}{c}\text { Número de } \\
\text { turistas } \\
(2)\end{array}$ & $\begin{array}{c}\text { Valor de uso } \\
\text { ponderado } \\
(\mathrm{em} \mathrm{R} \$)(1 \mathrm{x} 2)\end{array}$ \\
\hline 1 & $1.449,11$ & 04 & $5.796,44$ \\
2 & $3.620,03$ & 13 & $47.060,39$ \\
3 & $6.166,06$ & 41 & $252.808,46$ \\
4 & $2.564,84$ & 24 & $61.556,16$ \\
5 & $2.628,43$ & 11 & $28.912,73$ \\
6 & $4.103,22$ & 70 & $287.225,38$ \\
7 & $3.968,81$ & 83 & $329.411,23$ \\
8 & $4.514,08$ & 55 & $248.274,40$ \\
9 & $3.404,39$ & 16 & $54.470,24$ \\
10 & $5.772,45$ & 38 & $219.353,10$ \\
\hline TOTAL & $38.191,42$ & 355 & $1.534 .868,53$ \\
\hline
\end{tabular}

Fonte: Resultados da pesquisa

De acordo com o que pode ser observado na Tabela 12, verificouse que o valor de uso ponderado das praias do litoral cearense para os turistas amostrados no mês de novembro de 1995 foi de $R \$ 1.534 .868,53$.

Considerando-se que, no referido periodo, foram coletadas informações de 355 turistas, têm-se que o valor de uso das praias para cada turista nesse periodo, foi de $\mathrm{R} \$ 4.323,57$. Isso resultou num valor médio de uso de R\$144,12 por turista, por dia. Vale lembrar que, por falta de informaçōes sobre os turistas estrangeiros, só foram considerados, nessa análise, os turistas domésticos.

Estimativas feitas pela Secretaria do Turismo apontam que, em torno de $60 \%$, os turistas hospedam-se nos meios de hospedagem 
classificados e, 40\%, nos demais meios de hospedagem, ao longo de um ano. Com base nessa informação e considerando que foram 220.419 turistas que se hospedaram nos hotéis classificados de Fortaleza no ano de 1995 (Anuário, 1995), têm-se um total estimado de 367.365 turistas que visitaram o Estado do Ceará nesse ano.

Expandindo-se o valor de uso por turista encontrado para o total de visitantes no ano de 1995 tem-se um valor de uso de $R \$ 52.944 .643,00$, no agregado. Como ja foi dito anteriormente, aqui no Brasil não se conhece nenhum trabalho publicado utilizando essa metodologia com o recurso aqui valorado. Sendo assim, fica impossivel fazer comparações com os valores encontrados. 


\section{CONCLUSÕES}

Os resultados encontrados no presente estudo mostraram que, com relação ao perfil dos turistas que visitaram o Estado do Ceará no período analisado, os visitantes eram, na sua maioria, turistas domésticos $(93 \%)$. Com relação a idade, percebeu-se que a faixa etária que apresentou maior percentagem foi a de 31 a 40 anos. Dos turistas amostrados mais da metade (63\%) era do sexo masculino.

Com relação à renda familiar mensal dos entrevistados, percebeu-se que os mesmos tinham elevado poder aquisitivo, quando comparado com a maioria da população brasileira. Quanto ao nivel de escolaridade dos turistas, concluiu-se que os mesmos apresentam boa formação educacional, visto que $87 \%$ dos visitantes têm pelo menos o segundo grau completo.

O principal motivo de viagem dos turistas ao Estado do Ceará foi a procura de lazer e recreação. Considerando que a principal fonte fornecedora destes são as praias do litoral, concluiu-se que há necessidade de conservá-las, a fim de que se disponha sempre desse atrativo num periodo de longo prazo. Se as praias forem degradadas, a atividade turistica não será consolidada e isso resultara em uma fonte de renda a menos para o Estado, bem como irá reduzir o nivel de satisfação dos turistas.

A função de demanda por turismo no litoral cearense estimada pode ser classificada como inelástica no ponto médio, considerando o custo de viagem como o preço de "compra" do recurso em questão. Isso significa que, 
mantendo as demais variáveis constantes, um aumento nos custos de viagem, por exemplo de 1\%, irá reduzir a permanência média dos turistas no Estado do Ceará em $0,22 \%$, menos que proporcional.

Diante desse contexto pode-se concluir que as informações sobre a demanda turística servirá para um melhor planejamento dessa atividade no Estado do Ceará, uma vez que a partir da demanda real é possivel conhecer o perfil dos turistas o que permite uma melhor adequação da oferta dos serviços turisticos.

O valor de uso estimado para as praias do litoral cearense, considerando os 355 turistas amostrados foi de $R \$ 144,12$, por dia, por turista. Como a extensão do litoral cearense é de $573 \mathrm{~km}$, pode-se concluir que o valor de uso de um quilômetro de praia é de $R \$ 0,25$ por turista, por dia. Vale salientar que existem praias com diferentes niveis de qualidade ambiental e diferentes aspectos paisagisticos, o que provavelmente levará a valor de uso diferente do aqui estimado. Assim, sugere-se que pesquisas sejam desenvolvidas para estimar o valor de uso das diferentes praias do Estado.

Assim, pode-se concluir que as praias do litoral cearense são importante fonte de geração de beneficios para a sociedade brasileira e que por isso devem ser conservadas. Dessa forma, por se tratar de um recurso ambiental, e que possui características de bens públicos, devem ser fornecidas (conservadas) pelo poder público seja ele federal, estadual, ou municipal.

Além disso, sabendo-se que os beneficios do meio ambiente ou o valor total deste é composto pelo valor de uso, valor de opção e valor de existência, conclui-se que há necessidade de se desenvolver outras pesquisas para estimar o valor total das praias do litoral cearense. Diante disso, sugerese que sejam realizadas outros trabalhos utilizando não só a metodologia empregada nesse trabalho, como também outras em que seja possivel captar os diversos valores atribuidos ao meio ambiente. 
Como este trabalho foi executado com dados coletados no periodo de baixa estação, a equação de demanda estimada não pode ser utilizada para projetar a demanda anual, visto que esta será subestimada. Assim, sugere-se também que os trabalhos acima mencionados sejam desenvolvidos considerando os diversos meses do ano, para que se tenha conhecimento da demanda em cada periodo, bem como do valor total das praias do litoral do Estado do Ceará. 


\section{REFERENCIAS BIBLIOGRÁFICAS}

ADAMOWICZ, W. L. Valuation of environmental amenities. Canadian Journal of Agricultural Economics, v.39, n. 4, p. 609-618, Dez. 1991.

ADAMOWICZ, W. L; FLETCHER,J. J.; GRAHAM-TOMASI,T. Functional form and statistical properties of welfare measures. American Journal of Agricultural Economics, v.71, n. 2, p. 415-421, 1989.

ANUÁRIO ESTATÍSTICO DO CEARÁ. Fortaleza: IPLANCE, 1992 - 1995.

BELL, F. W. ; LEEWORTHY, V.R. Recreation demand by tourists for saltwater beach days. Journal Environmental Economics and Manegement, v.18, n. 3, p. 189-205, 1990.

BELLUZZO Jr., W. Valoração de bens públicos: o método de avaliação de contingente. São Paulo, 1995. 151 p. Dissertação (M.S.) - Faculdade de Economia Administração e Contabilidade, Universidade de São Paulo.

BONTEMPO, M. Análise sócio-econômica do turismo ecológico no Brasil: um estudo de caso. Viçosa, 1994. 117 p. Tese (M. S.) - Universidade Federal de Viçosa.

BROWN, W. G.; SORHUS, C.; CHOU-YANG, B-L.; RICHARDS, J. A. Using individual observations to estimate recreation demand functions: a caution. American Journal Agricultural Economics, v. 65 , n. 1, p. 154-157, Feb. 1983. 
BURNIE, D. Ecoturist to paradise. New Scientist, v.142, p. 23-24, 1994.

CARACRISTI, M. F. A. Hotéis e barracas de praia - o fenômeno do turismo no crescimento econômico da cidade de Natal-RN. São Paulo, 1994. 188 p. Dissertação (M.S.) - Escola de Comunicação e Artes, Universidade de São Paulo.

CEARÁ (Estado). Secretaria de Turismo. Instituto de Planejamento do Ceará. Pesquisa de demanda turistica. Fortaleza: SETUR, 1995a.

CEARÁ (Estado). Secretaria de Turismo. Sintese das informações turisticas. Fortaleza: SETUR, 1995b.

CESARIO, F. J. Value of time in recreation benefit studies. Land Economics, v. 52 , n. 1 , p. 32-41, Feb. 1976.

CUMMINGS, R. G.; BROOKSHIRE, D. S.; SCHULZE, W. D. Valuing environmental goods: an assessment of the contingent valuation method. Totowa, New Jersey: Rowman \& Allanheld, 1986. 269p.

D'AMORE, L. J. Tourism: the word's peace industry. Recreation, v. 48 , n. 1, p. 24-33, 1990.

DESVOUSGES, W. H.; GABLE, A. R.; DUNFORD, R. W.; HUDSON, S. P. Contingent valuation: the wrong tool to measure passive-use losses. Choices, p. 9-11, second quarter, 1993.

DIXON, J. A. ; SHERMAN, P. B. Economics of protected areas: a new look at benefits and costs. Washington: Island Press, 1990. 234 p.

DIXON, J. A.; SHERMAN, P. B. Economics of protected areas. Ambio, v. 20, n. 2, p. 68-74, Apr. 1991. 
ELY, A. Economia do meio ambiente. Porto Alegre: Fundação de Economia e Estatistica, 1986. 146 p.

FREEMAN III, A. M. The benefits of environmental improvement: teory and practice. Baltimore: Johns Hopkings, 1979. p. 195-233.

GIBBS, K. C. Evaluation of outdoor resources: a note. Land Economics, v. 50, n.3, p. 309-311, Aug. 1974.

GRASSO, M.; TOGNELLA, M. M. P.; SCHAEFFER-NOVELLI, Y.; COMUNE, A. E. Aplicação de tẻcnicas de avaliação econômica ao ecossitema manguezal. In: MAY, P. H. (org.) Economia ecológica: aplicações no Brasil. Rio de Janeiro: Campus, 1995. p. 49-81.

GUIA PANROTAS. São Paulo: Panrotas, nov. 1995. 256 p.

GUIA BRASIL QUATRO RODAS. São Paulo: Abril, 1996. 545 p.

HUFSCHMIDT, M. M.; JAMES, D. E.; MEISTER, A. D.; BOWER, B. T.; DIXON, J. A. Environmental, natural systems, and development: an economic valuation guid. London: Johns Hopkins, 1983. 338 p.

JUDGE, G. G.; HILL, R. C.; GRIFFTHS, W. E.; LÜTKEPOHL, H.; LEE, T-C. Introduction to the teory and practice of econometrics. 2. ed., New York: John Wiley \& Son, 1988.1024 p.

KRUTILLA, J. V. Conservation reconsidered. The American Economic Review, v. 57, p. 777-786, 1967.

LAGE, B. H. G.; MLONE, P. C. Economia do turismo. São Paulo: Papirus, 1990.

LOPES, J. C. O turismo e o desenvolvimento regional do norte e nordeste. Informações FIPE, n. 120, p. 15-17, jul. 1990. 
MCCONNELL, K. E. Congestion and willingness to pay: a study of beach use. Land Economics, v. 53, n.2, p. 185-195, May 1977.

The economics of outdoor recreation. In: KNEESE, A. V. E SWEENEY, J. L. Handbook of natural resource and energy economics. Amsterdam: Elsevier Science, 1985. p. 677-722.

McCONNELL, K., E.; STRAND, I. Measuring the cost of time in recreation demand analysis: an aplication to sportfishing. American Journal of Agricultural Economics. v. 63, n. 1, p. 152-156, Feb. 1981.

MELO, D. N. de. Tópicos do fenômeno turistico. Fortaleza, 1988. (mimeo.).

NAVRUD, S.; MUNGATANA, E. D. Environmental valuation in developing countries: the recreational value of wildilife viewing. Ecological Economics, v. 11, n.2, p. 135-151, 1994.

NICKERSON, P. H. Demand for regulation of recreation: the case of elke and deer hunting in Washigton State. Land Economics, v. 66, n.4, p. 437447, Nov. 1990.

PEARCE, D. W.; TURNER, R. K. Economics of natural resources and the environment. 2. ed. Baltimore: Johns Hopkins Univ. Press, 1990. 378 p.

PEARSE, P. H. A new approach to the evaluation of non-priced recreational resources. Land Economics, v. 44, n.1, p. 87-99, Feb. 1968.

PESSOA, R.; RAMOS, F. S. Avaliação de ativos ambientais: aplicação do método de avaliação contingente. In: ENCONTRO BRASILEIRO DE ECONOMETRIA, 23., Águas de Lindóia, 1996. Anais. Rio de Janeiro: SBE, 1996. v. 2, p. 679-694.

PINDYCK, R. S.; RUBINFELD, D. L. Microeconomia. Sāo Paulo: Makron Books. 1994. 968p. 
RABAHY, W. A. Planejamento do turismo: estudos econômicos e fundamentos econométricos. São Paulo: Loyola, 1990.

RANDALL, A. Resource economics: an economic approach to natural resouce and environmental policy. 2. ed., New York: John Wiley \& Son, 1987. 434 p.

RICHARDS, M. T.; BROWN, T. C. Economic value of campground visits in Arizona. Colorado: USDA. Forest Service, 1992. 23 p. (Research Paper RM-305).

RUSCHMANN, D. M. O planejamento do turismo e a proteção do meio ambiente. São Paulo, 1994, 267 p. Tese (Doutorado) - Escola de Comunicaçōes e Artes, Universidade de São Paulo.

SCHULZE, W. D.; D'ARGE, R. C.; BROOKSHIRE, D. S. Valuing environmental commodities: some recente experiments. Land Economics, v. 57, n. 2, p. 151-172, May 1981.

SILBERMAN, J.; GERLOWSKI, D. A.; WILLIAMS, N. A. Estimating existence value for users and nonusers of New Jersey beachs. Land Economics, v. 68 , n. 2, p. 225-236, May 1992.

SILBERMAN, J.; KLOCK, M. The recreation benefits of beach renourishment. Ocean \& Shoreline Mangement, v. 11, n. 2, p. 73-90, 1988.

SMITH, V. K.; KAORU, Y. Signals or noise? Explaining the variation in recreation benefit estimates. American Journal of Agricultural Economics, v. 72, n. 2, p. 419-433, May 1990.

STRONG, E. J. A note on the functional form of the travel cost models with zones of unequal populations. Land Economics, v. 59, n. 3, p. 342349, 1983. 
TISDELL, C. A. Economics of environmental conservation: econonomics for environmental and ecological management. Amesterdam: Elsevier Sciense, 1991. p. 123-139.

TOBIAS, D.; MENDELSOHN, R. Valuing ecotourism in a tropical rain-forest reserve. Ambio, v. 20, n. 2, p. 91-93, Apr. 1991.

TOGNELLA, M. M. P. Valoração econômica: estudo de caso para o ecossistema manguezal - Bertioga e Cananéia, Estado de São Paulo. São Paulo, 1995. 161 p. Dissertação (M. S.) - Instituto Oceanográfico, Universidade de São Paulo.

TRANSPORTE MODERNO. São Paulo, n. 372, dez. 1995. 46 p.

WALSH, G. R.; LOOMIS, J. B.; GILLMAN, R. A. Valuing option, existence and bequest demand for wilderness. Land Economics, v. 60 , n.1, p. 14-29, Feb. 1984.

WILLIS, K. G.; GARROD, G. D. An individual travel-cost method of evaluating forest recreation. Journal of Agricultural Economics, v. 42 , n. 1, p. 3342, Jan. 1991.

ZIEMER, R. F.; MUSSER, N. W.; HILL, R. C. Recreation demand equations: funtional form and consumer surplus. American Journal of Agricultural Economics, v.62, n.1, p.136-141, Feb. 1980. 